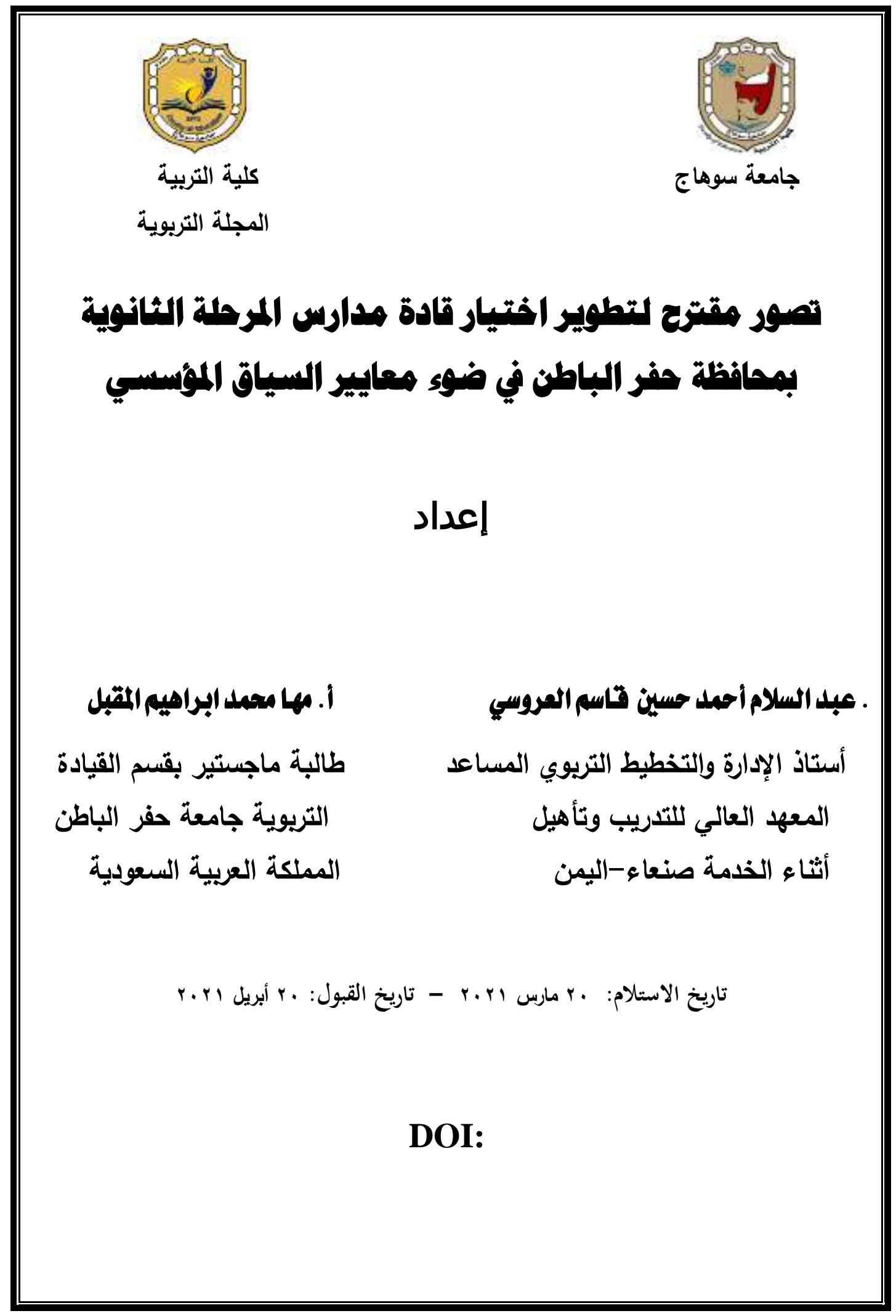




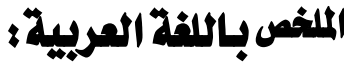

هدفت الدراسة إلى تطوير اختيار قادة المدارس بالمرحلة الثانوية بححافظة حفر الباطن في ضوء معايير السياق المؤسسي، ولتحقيق الهلف الرئيس للاراسة اتبع الباحثان المنهج

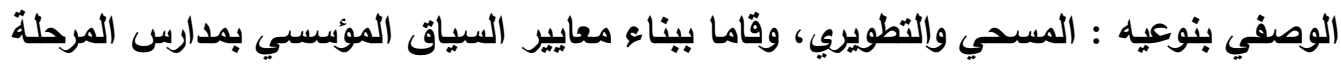

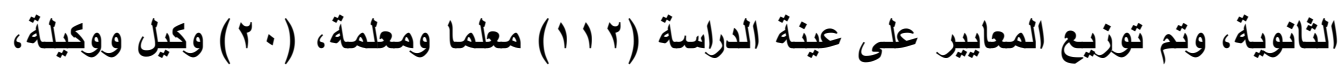

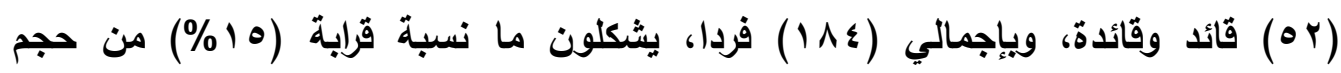
المجتمع الأصل للاراسة، وأفرزت الاراسة النتائج الآتية:

بناء تصور مقترح لتطوير اختيار قادة الدارس بالمرحلة الثانوية في محافظة حفر الباطن في ضوء معايير السياق المؤسسي.

إن درجة أهمية اختيار قادة الدارس بالمرحلة الثانوية بمحافظة حفر الباطن في

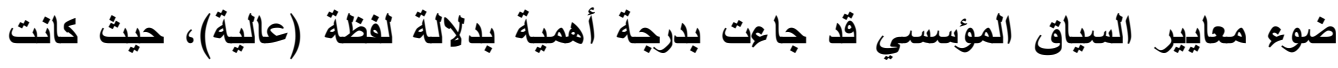

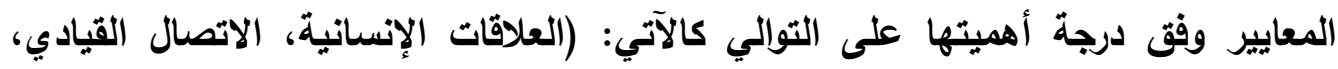

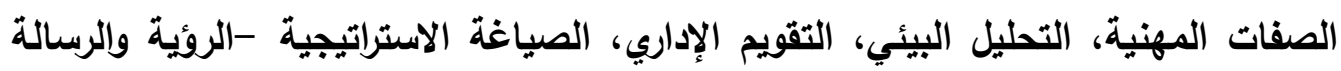

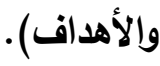

لا توجد فروق ذات دلالة إحصائية في استجابات أفراد عينة الاراسة لواقع اختيار

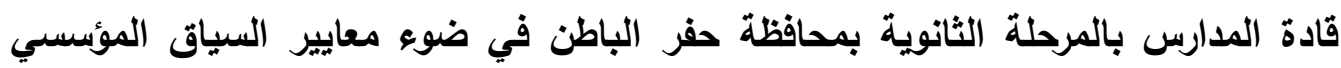
تعزى لمتغير النوع الاجتماعي، ومتغير سنوات الخدمة، ومتغير المؤهل العلمي باستثناء فئهي

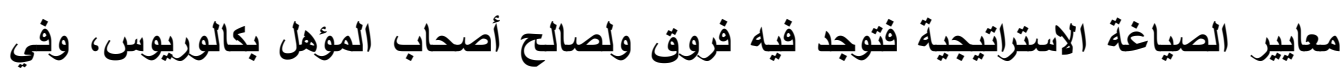

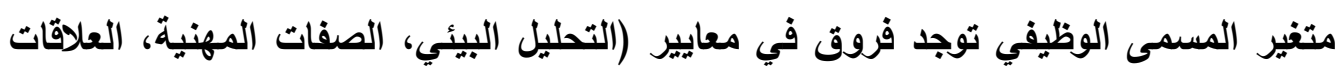
الإنسانية، التقويم الإداري) لصالح القيادات المدرسية على المعلمين فقط. وقدمت الدراسة العديد من التوصيات والمقترحات. الكلمات المتتاهية : تطوير، اختيار قادة المدارس، معايير السياق المؤسسي. 


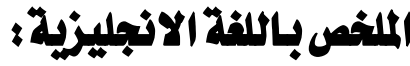

The study aimed to develop the selection of school leaders in the secondary stage in Hafar Al-Batin governorate in light of the institutional context criteria, and to achieve the main objective of the study, the two researchers followed the descriptive approach of its two types: survey and development, and they built standards for the institutional context in secondary schools, and the criteria were distributed among the study sample (112) teachers (males, and females), (20) vice principal (males, and females), (52) leaders and (males, and females), and a total of (184) individuals, make up about (15\%) of the size of the community of origin for the study, and the study yielded the following results:

Building a proposed vision to develop the selection of school leaders at the secondary level in Hafar Al-Batin governorate in light .of the institutional context criteria

$\square$ The degree of importance of selecting school leaders at the secondary stage in Hafar Al-Batin governorate in light of the institutional context criteria came with a degree of importance in relation to the word (high), where the criteria were according to the degree of their importance, respectively, as follows: (human relations, leadership communication, professional qualities, environmental analysis Administrative calendar, strategy formulation - vision, mission and goals).

$\square$ There are no statistically significant differences in the responses of the study sample individuals to the reality of choosing school leaders at the secondary stage in Hafar Al-Batin governorate in light of the institutional context criteria due to the gender variable, the years of service variable, and the academic qualification variable except for the strategic formulation criteria. In the variable of job title, there are differences in criteria (environmental analysis, professional qualities, human relations, administrative evaluation) in favor of school leaderships over teachers only.

The study made many recommendations and suggestions.

Key words:

Develop, School leaders Selection , Institutional Context Criteria . 


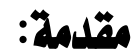

تعل القيادة في أية مؤسسة معاصرة وفي طليعتها المؤسسات التعليمية بمثابة الدينامو

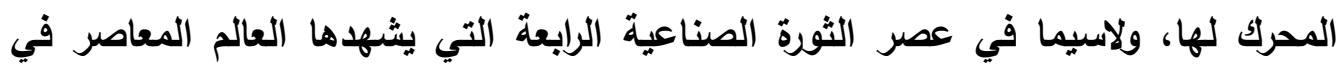
العقد الثالث من القرن الحادي والعشرين، وعلى قدر كفاءة مستوى هذه القيادة، يتوقف جودة فئاة

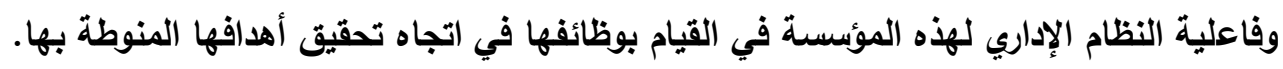
كما يشها العصر الحالي الكثير من التغيرات المتسارعة والمستمرة على كافة الاصعدة،

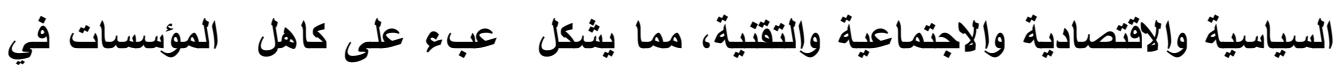
كيفية التعامل والتكيف مع هذه التغيرات مع ضمان المحافظة على الهوية المؤسسية بالتوازي

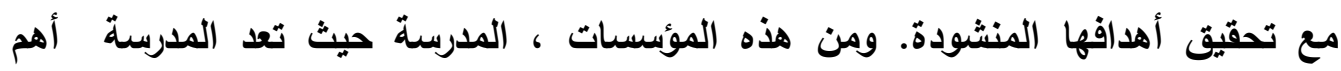

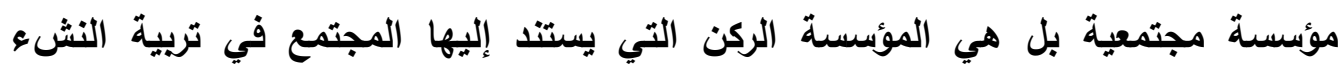

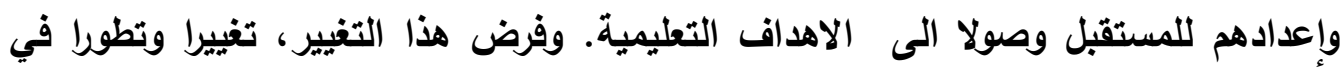

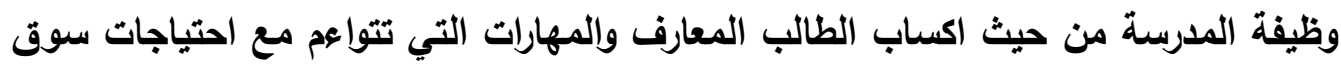
العمل ومتطلبات العصر، وتهيئته كي يصبح عنصر فعال في المجتمع (معايير القيادة

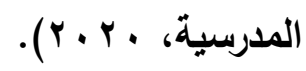
والتغير الوظيفي للمدرسة ألزم الاهتمام بوضع الثخصية القيادية المناسبة التي تتولى قيادة

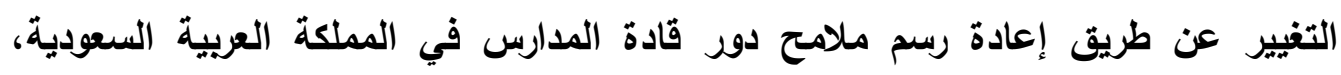

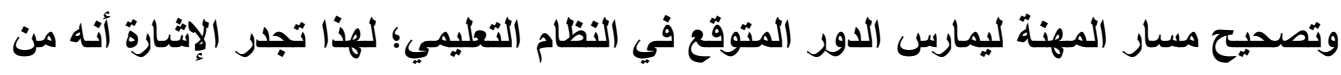
المهم جذا أن ينظر لعمليات توظيف قادة المدارس، وتقييمهم، وتطوير مهاراتهم بثكل مستمر

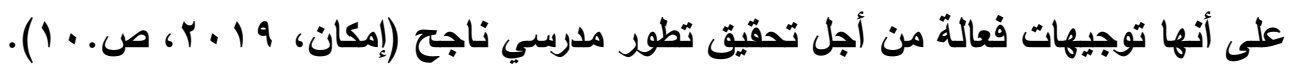

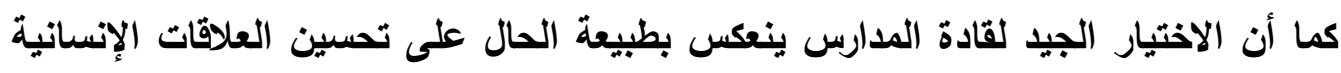
والاجتماعية بين العاملين، الأمر الذي يعمل على تعزيز ثقته بنفسه، ويزيد من انسجامه الإنائ

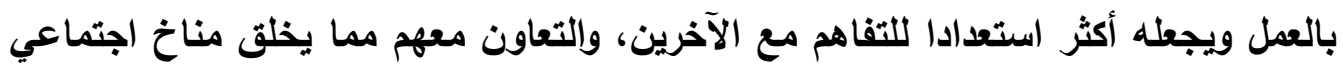

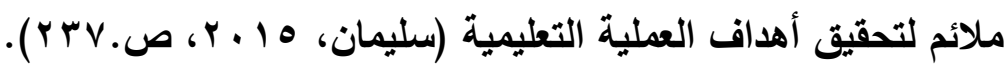




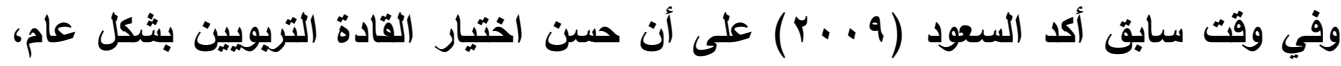

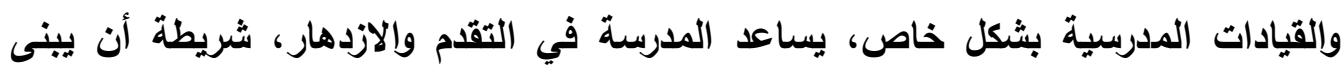
الاختيار على معايير محددة.

ولقد أضحت قضية التظوير التظيمي لمؤسسات التعليم العام بشكل عام من القضايا الجوهرية في مجال إدارتها، وكذلك من الاتجاهات الحديثة في إدارة المؤسسات التريوية، والتي تركز على تطبيق ممارسات معايير التخطيط الاستراتيجي والسلطة، والإدارة؛ نظرا لما لها من أهمية وارتباط بمفاهيم إعادة الهيكلة، فمن خلالها يمكن التظلب على الكثير من لمنيل الصعويات والتحديات التي تواجه جهود التطوير والتحسين (النصير؛ والقيسي؛ والرواثدة؛

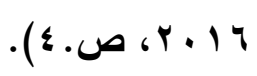
وعليه، فقد بدأت المؤسسات في التسابق نحو صياغة المعايير التي يتم قياس الأداء على أساسها، والتي تتضمن السياسات، وتوزيع السلطة، ومدى استخدام فرق العمل، والتنظيم والتتمية، والتحليل والمقدرة على التخطيط للمستقبل (Berwari and Bashiwa, 11 1 ـ ץ). واختيار قادة المدارس في المملكة العربية السعودية يكون من داخل المؤسسات التريوية، فلا يعين القائد المدرسي إلا بعد أن يمارس مهام وكيل المدرسة لمدة سنتين على الأقل و بتقدير

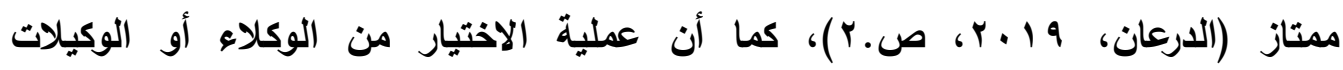
المرشحات تعد إحدى العمليات في سياسة التوظيف في وزارة التعليم، حيث تعمل إدارات

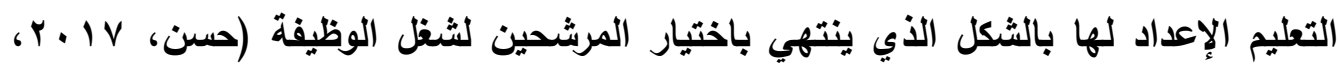
. (^). وقد رأت وزارة التعليم في المملكة أن تطبيق ضوابط الاختيار والتعيين لقادة المدارس يحقق

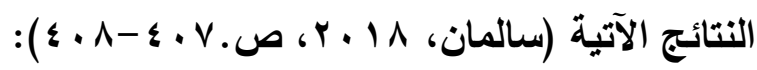
ا ـ المهنية: إن تطبيق المعايير في عملية اختيار وتعيين قادة المدارس ينتج عنه دعم النظام التعليمي بالكفاءات الإثرافية، والقيادية التي تتمتع بقدر من المهنية العالية في الأداء الإشرافي والقيادي. r. المعيارية: في الترشيح والتكليف؛ بحيث ياخل إلى المواقع الإشرافية والقيادية من تتوفر فيه ضوابط ومواصفات محددة لهذا العمل من حيث الجدارة. 
r. الكفاءة: حيث إن من سيدخل إلى المواقع الإثرافية والقيادية من خلال المعايير الموضوعة من المتوقع أن يتمتع بقر كبير من الكفاءة الأدائية التي من شأنها أن ترفع من النية إنى إنتاجية العمل التريوي والتعليمي. ع. الشمولية: هذا الإطار التظيمي قد وحد معايير وضوابط وإجراءات الترشيح والتكليف؛ لتشمل جميع القياديين والمشرفين في النظام التعليمي على مستوى المدرسة وإدارة التربية والتعليم وجهاز الوزارة. هـ التفاعلية: حيث إن هذه الفئة التي تتمتع بها المستوى من المهنية وإلتأهيل والتميز؛

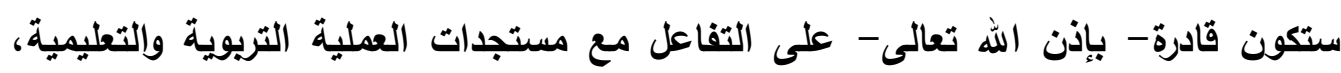
وتطوراتها المتسارعة. أما عن اختيار قادة المدارس بإدارة التعليم بمحافظة حفر الباطن بالمملكة العربية السعودية، وانطلاقا من الدور الذي تؤديه القيادات التريوية في وزارة التعليم في تطوير العملية التريوية والتعليمية وتقويمها، اقتضت ضرورة العمل اختيار الكفاعات المتميزة للقيام بمختلف المهام والأدوار التربوية والتعليمية في مختلف المواقع؛ لتحقيق الجودة النوعية، وذلك يتطلب وضع ضوابط محددة للتكليف تشمل شاغلي الوظائف التعليمية في المدارس، وإدارات التعليم،

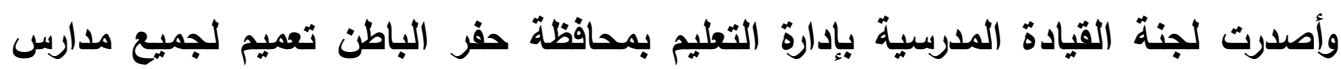

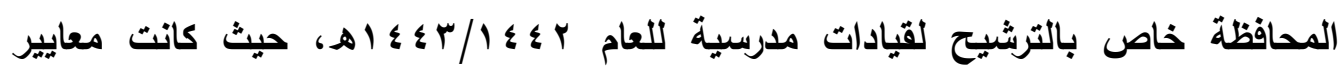
الترشيح كالآتي:

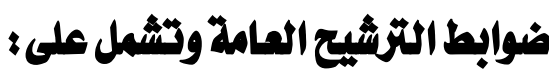

- أن يكون المرشح ذا مؤهل جامعي تريوي. - أن لا تقل خبرته عن أربع سنوات للمعلمة المرشحة. - أن لا يقل تقدير الأداء الوظلفي عن ممتاز. - أن لا يكون قد صدر بحقه عقوية نظامية خلال الثلاث سنوات الأخيرة أو أن يكون طرف في قضية نظر أو لها معاملة تحقيق جارية. - أن لا يتجاوز غياب- عدا إجازات الوضع (للنساء) والحداد- خلال العامين الأخيرين

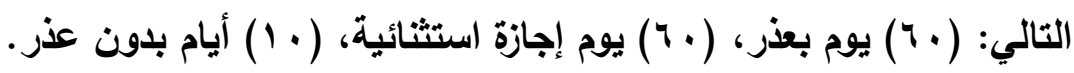


ثانيا السمات الشئخصية:

- القدوة الحسنة.

- السيرة السلوكية والتتريوية.

- سلامة الحواس (السمع والبصر). - القدرة على الإقتاع. - المهارة في الحوار.

- القدرة على تحليد الأولويات المهنية. - التعامل الإيجابي في المواقف التريوية المختلفة. - القدرة على بناء علاقات إيجابية مع الآخرين. - للايها أفكار تطويرية في مجال العمل. - الصبر لتحقيق الأهداف التريوية. - التفاعل مع الأعمال التريوية الجماعية. - القدرة على التأثير على الآخرين. - القدرة على اتخاذ القرار المناسب. - - الثقة بالنفس. - الاهتمام بأوقات الدوام. - المات - مستوى الدافعية للعمل. كالثا المهارات والقداتة - الإلمام بالتغصص. - إتقان المهارات المتصلة بالمادة العلمية. - ريط موضوع الدرس بالأحداث المحيطة. - ريط موضوع الدرس بفروع التخصص الأخرى. - ريط موضوع الارس بالمواد العلمية الأخرى. - استخذام مراجع إضافية في الإعداد لدرسها. 
- الاهتمام بتجديد البيئة الصفية. - استخدام لغة واضحة ومناسبة لمستوى الطالبات. - إثارة دافعية التلميذات باستمرار وتجذب انتباههم. - تعزيز الاستجابات وتقبل أفكار الطالبات. - طرح أسئلة متنوعة ومثيرة للتفكير. - التتظيم والتدرج في عرض المعلومات. - توجيه عملية التعليم وليس السيطرة عليها. - توفير بيئة آمنة من الخوف من الخطأ. - تنوع في أساليب التدريس. - تنوع في استخدام التقنيات التعليمية. - توفير بيئة تريوية مشجعة للتقويم الذاتي. والمتتبع لحال التعليم في المملكة العربية السعودية بشكل عام، يجد العناية الكبيرة واللدعم الهائل من القيادة الحكيمة لتطوير التعليم، فقد نال التعليم اهتماما كبيرا منذ أن أنشئت المملكة العربية السعودية، واستمر هذا الاهتمام إلى السنوات الحاضرة- وسيستمر بإذن الله تعالى - ومن مؤشرات هذا الاهتمام ما يخصص للتعليم من ميزانية الدولة، وقد شهد التعليم

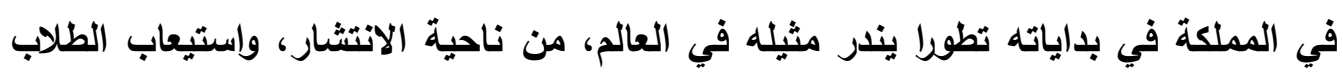

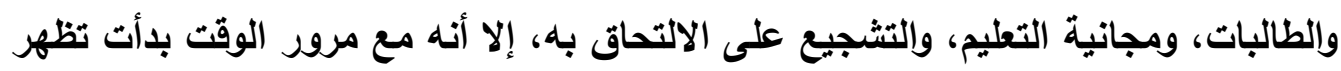
مشكلات تواجه هذا النظام التعليمي، وتحتم التطوير والتجديد لمعالجة تلك المشكلات، وخلق الته

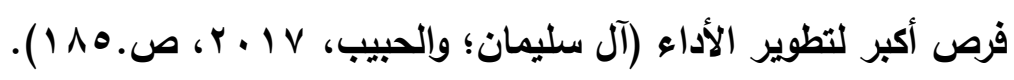

وتعد القيادة المدرسية العمود الفقري وحجر الزاوية في المؤسسة التعليمية وتظهر الحاجة

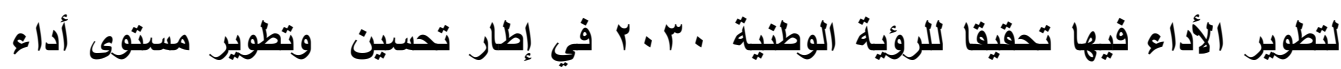
المؤسسات التريوية والتعليمية في المملكة العربية السعودية وصولا لتحقيق الأهداف المنشودة. وأدى تطور الدور الوظيفي للمدرسة إلى ارتفاع مستوى التأهيل المطلوب من

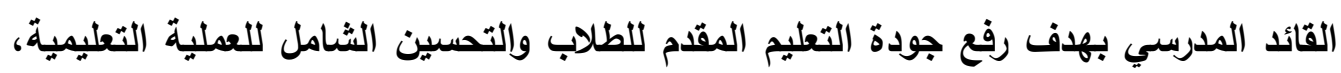


من نقطة البداية من خلال التركيز على (القيادة المدرسية) و ضمان اختيار الكفاءة المطلوية كلانضمام إلى مهنة القيادة المدرسية. ويعتبر قادة المدارس منطلق نجاح مدارسهم، ومحو ارتكازها، وداعم رئيسي لكل منتسبيها

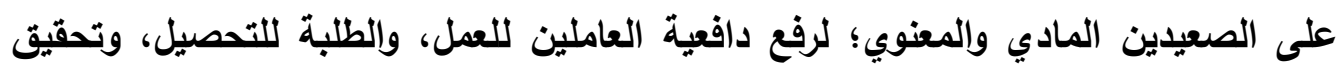

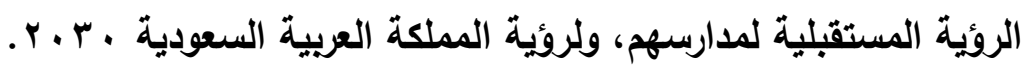
ويعرف قائد المدرسة بأنه: "المسؤول الأول عن إدارة المدرسة وتوفيهة وليهية البيئة التعليمية المناسب فيها، والمشرف الدائم لضمان سير العملية التريوية وتنسيق جهود العاملين فيها

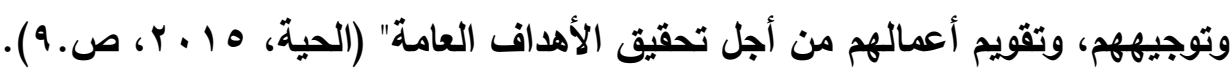

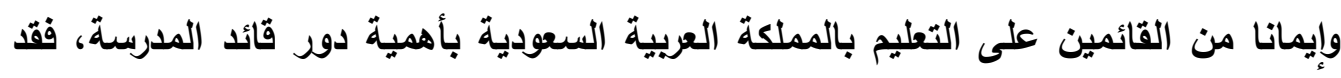

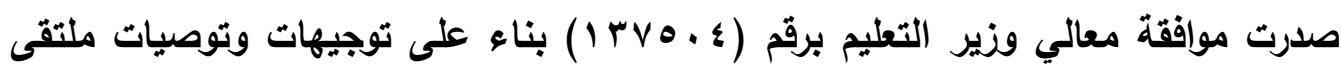

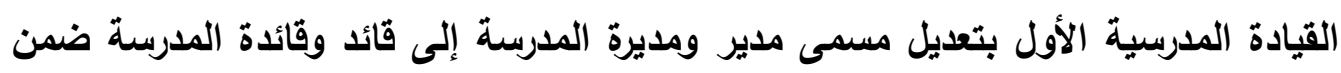

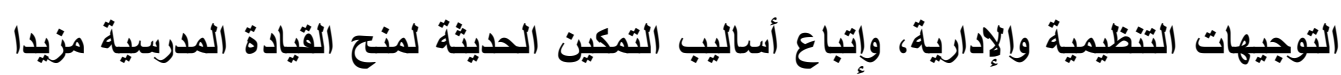

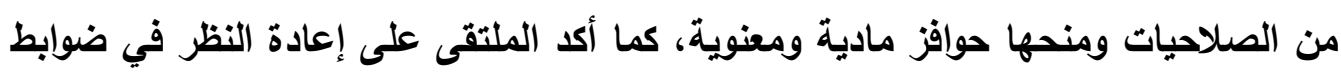
وآليات اختيار القيادات المدرسية وفق متطلبات المستقبل بناء على معايير الجدارة، وتقبل التغيير والتطوير الإيجابي، والاستفادة من فرصة دمج التعليم العام، والتعليم العالي في مجال

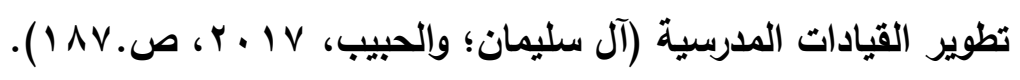

وقد أجريت العديد من الدراسات التي سعت إلى تطوير نظام اختيار وتدريب قادة المدارس

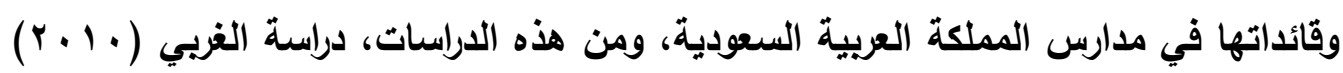
التي هدفت إلى تقويم معايير اختيار مديري المدارس الثانوية العامة بالمملكة العربية السعودية، وذلك من خلال تشخيص واقع الإدارة المدرسية في المرحلة الثانوية العامة بمنطقة

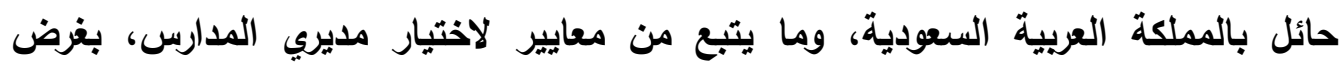
الكثف عن جوانب القصور في تلك المعايير، من خلال عينة من مجتمع البحث وهم مديرو المدارس الثانوية العامة بمنطقة حائل، وتم اتباع المنهج الوصفي المسحي، وطبق عليهم استبانة، وتوصلت الدراسة إلى العديد من النتائج ومنها: تقديم تصور مقترح لمعيار ملائم

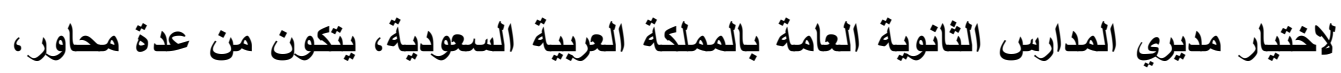




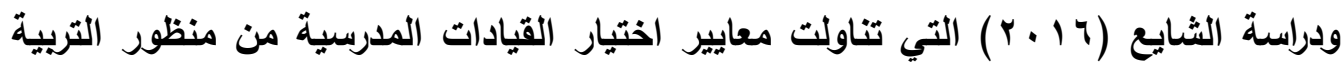
الإسلامية ومدى توافرها في مديري المدارس الثانوية بمنطقة القصيم، واستخدمت الدراسة المنهج الوصفي المسحي، وتم تطبيق استبانة على عينة الاراسة، وتوصلت إلى النتائج الآتية: إن المعايير الأساسية لاختيار مدير المدرسة تتحدد من منظور التربية الإسلامية في القوة والأمانة، ثم تأتي بقية المعايير تباعا، وأن توافر المعايير الإسلامية المتصلة بالصفات الإنيل الشخصية في مديري المدارس الثانوية بمنطقة القصيم بدرجة كبيرة، ووجود فروق ذات دلالة إحصائية تعزى لمتفير النوع الاجتماعي لصالح الذكور، بينما لا توجد فروق ذاتيه لاته دلالة إحصائية تعزى لمتغيرات: موقع المدرسة، والمؤهل، والتخصص، وسنوات الخبرة، ودراسة

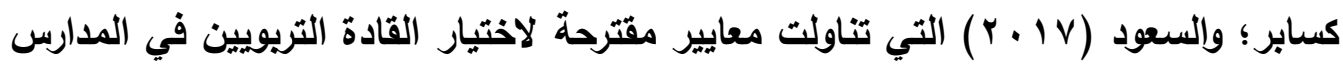
الخاصة في فلسطين في ضوء الواقع وأبعاد الجودة الشخصية، واستخدمت الاراسة المنهج الوصفي التحليلي، وتم تطبيق استبانة على عينة الدراسة، وتوصلت إلى أن درجة مماسة اختيار القادة التريويين حسب المعايير الموضوعة مرتفعة، ثم تم تطوير معايير لاختيار القادة التريويين في المدارس الخاصة في فلسطين في ضوء الواقع وابعاد الجودة الشخصية، ودراسة تطوية

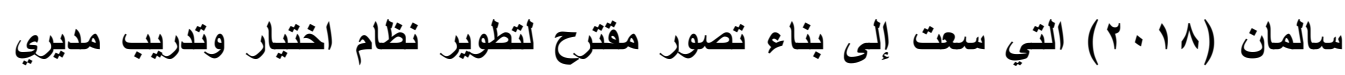

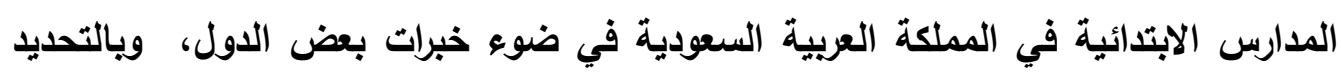
خبرة ماليزيا ومصر، واستخدمت الدراسة المنهج الوصفي، وتوصلت إلى أن عملية اختيار

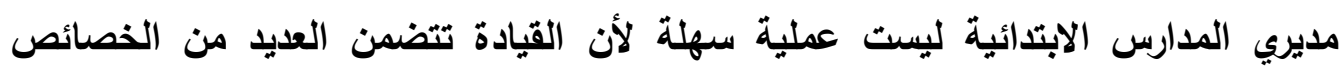
المهنية والثخصية التي يجب أن تثوفر في مدير المدرسة الابتدائية، وأما بالنسبة للتدريب

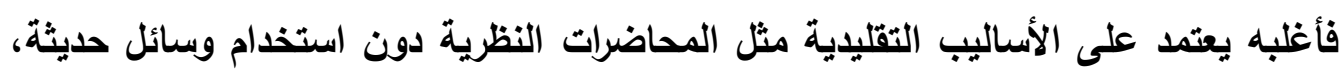
كما أن معايير الاختيار ويرامج التدريب تحتاج إلى مراجعة دقيقة، ووضع استراتيجية

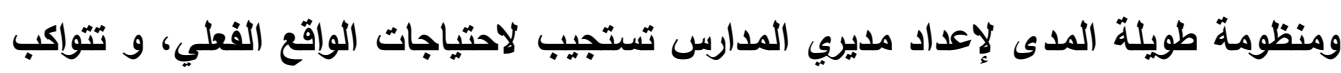

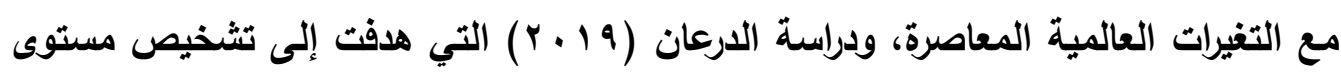
رضا وكلاء مدارس التعليم العام بمدينة تبوك عن عملية اختيار قادة المدارس، واستخدمت

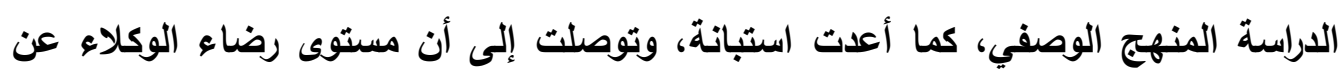
عملية اختيار قادة المدارس في مدينة تبوك جاء بدرجة متوسطة، وعدم وجود فروق ذات 
دلالة إحصائية حول مستوى رضا الوكلاء عن عملية اختيار قادة المدارس وفقا لمتغيرات المرحلة، وعدد الدورات التدريبية، والخبرة.

وفي ضوء العرض السابق للاراسات السابقة، يتبين أنها: تنوعت في تناولها معايير اختيار

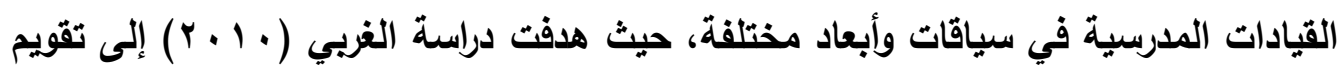
معايير اختيار مديري المدارس الثانوية العامة بالمملكة العربية السعودية، وتتاولت دراسة

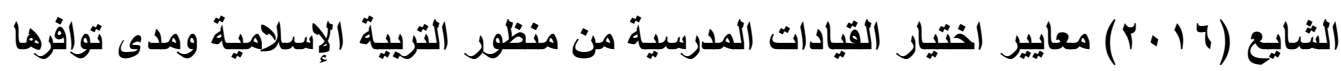

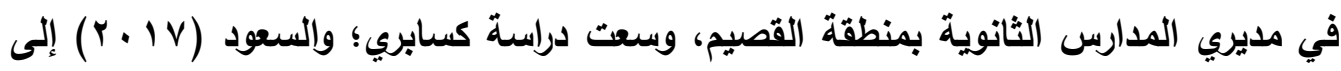
بناء معايير مقترحة لاختيار القادة التريويين في المدارس الخاصة في فلسطين في ضوي وائه

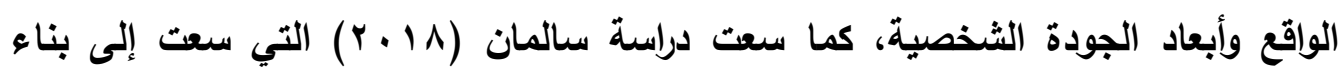
تصور مقترح لتطوير نظام اختيار وتدريب مديري المدارس الابتدائية في المملكة العربية

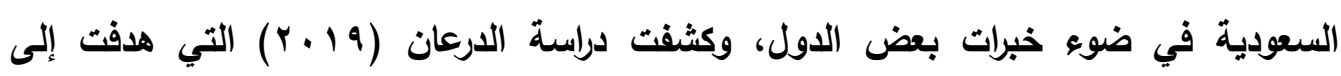
تثخيص مستوى رضا وكلاء مدارس التعليم العام بمدينة تبوك عن عملية اختيار قادة المدار. وتتثابه الدراسة الحالية مع الدراسات السابقة في موضوعها، خاصة التي تناولت اختيار

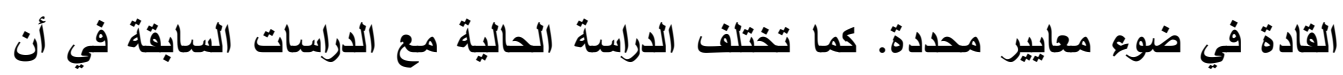
الدراسة الحالية تسعى إلى تطوير اختيار قادة المدارس بالمرحلة الثانوية، وطبقت في محافظة

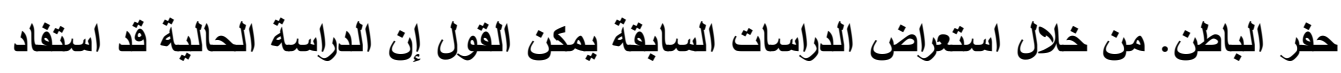
من الدراسات السابقة التي تم الاطلاع عليها في جواتب متعددة، من أهمها الآتي: الإفادة من

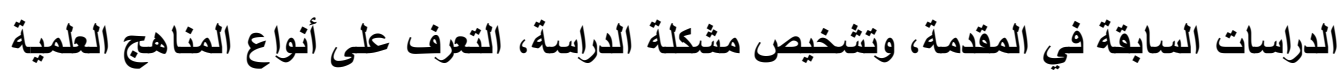

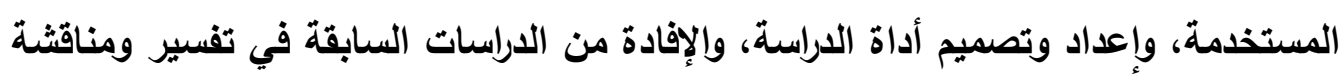
نتائج الاراسة الحالية. فمن هنا أتت هذه الدراسة والتي اعتمدت على معايير السياق المؤسسي لتطوير اختيار قادة المدارس بالمرحلة الثانوية بمحافظة حفر الباطن.

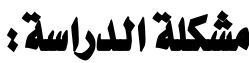

انطلاقاً من إدراك المملكة العربية السعودية العميق لأهمية الموارد البشرية، والاستثمار في التعليم، وتنمية قدرات أبنائها؛ ليصبحوا جيل المستقبل القادر على تحقيق تقدم البلاد 
وازدهارها، فإنها تولي اهتمام خاص بالنشء، ومن ثم تضع السياسات والبرامج والمقررات اللازمة لذلك.

وعلى الرغم من الجهود الحثيثة التي تقوم بها وزارة التعليم في المملكة العربية السعودية

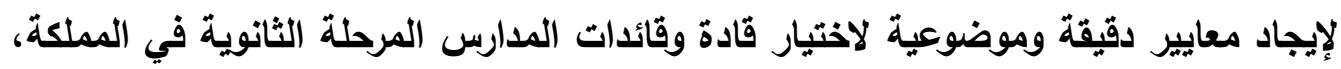
وما نجم عن ذلك من إنجازات ملموسة، إلا أنه وياستقراء العديد من التقارير الرسمية والأبحاث العلمية التي كثفت عن وجود بعض الثغرات والاختلالات العلمية والمهنية في اختيار هؤلاء القادة والقائدات، ومن ضمنها تجاوز البعض لهذه المعايير ولا تنطبق عليهم

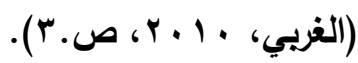

كما شهدت السنوات الماضية اتجاها جديدا في الإدارة المدرسية ضمن ثورة التطورات المعاصرة، والتقنيات الحديثة، حيث لم يعد تسيير شؤون المدرسة روتينيا، أو مجرد المحافظة على النظام المدرسي، بل أصبح محور العمل في الإدارة المدرسية يدور حول الطالب، ويناء عليه ينبغي أن تتوافر مجموعة من المعاييز والضوابط لمن يمسك بزمام القيادة المدرسية؛ ليساعد الطلاب على توجيه النمو العقلي والبدني والروحي وصولا إلى تحسين العملية

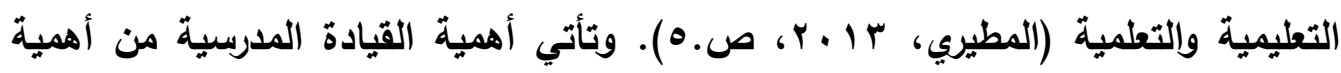
الدور الذي تقوم به لتحقيق الاهداف التعليمية فطبيعة عملها يقوم على التعامل مع أفراد

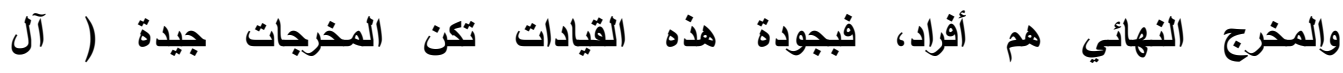

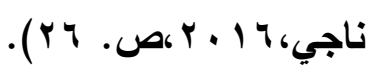
كما يجب أن يعمق التوجه الاستراتيجي المستقبلي في كافة الممارسات الادارية لقادة المدارس

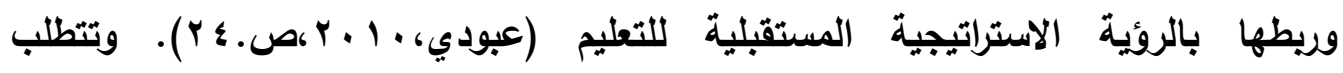
الإصلاحات التعليمية أن يتولى قادة المدارس قيادة مسيرة التغيير؛ وعليه فمن الضروري بناء قرات قادة المدارس الحاليين و المستقبليين في المملكة العربية السعودية وتسليحهم بالمعرفة

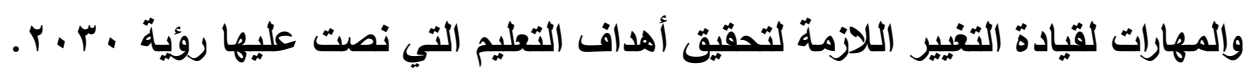
كما أن هناك توجه قوي يسعى إلى الارتقاء بكفاءة النظام التعليمي بمستوييه الداخلي

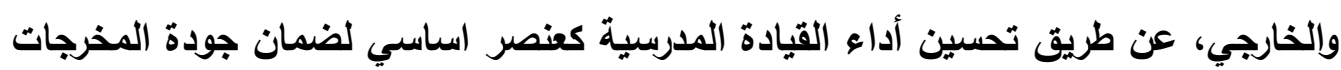

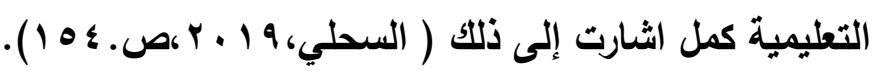




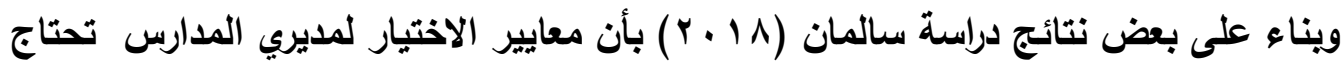

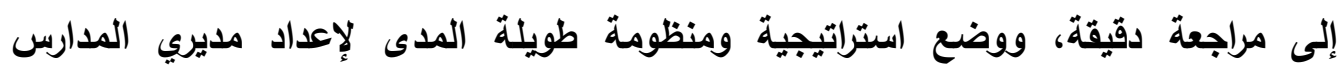
تستجيب لاحتياجات الواقع الفعل، و تتواكب مع التغيرات العالمية المعاصرة. كما أوصت

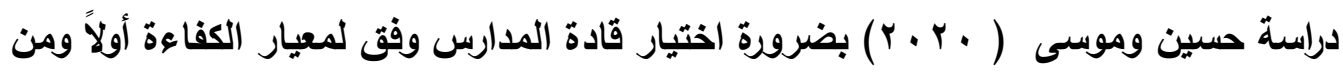
ثم تكون عملية الاختيار وفق معايير علمية وشروط خاصة لاختيار القادة.

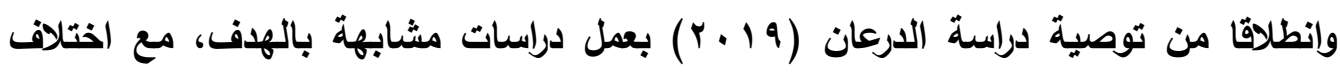
العينة لعملية اختيار قادة المدارس، وفي ضوء معايير أخرى، تأتي هذه الدراسة. وفي ضوء ما سبق؛ فإن مشكلة الدراسة تتمثل في كيفية تطوير اختيار قادة المدارس بالمرحلة الثانوية بمحافظة حفر الباطن في ضوء معايير السياق المؤسسي، وهكذا تتبلور

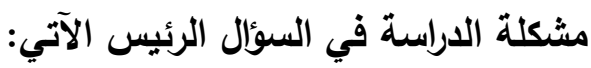

\section{تصساؤات الثلدراسة}

يكمن سؤال الدراسة الرئيس في: كيف يمكن تطوير اختيار قادة المدارس بالمرحلة الثانوية بمحافظة حفر الباطن في ضوء معايير السياق المؤسسي؟ وللإجابة عنه يتفرع منه الأسئلة الآتية:

1 - ما الإطار النظري لأساليب اختيار القيادات المدرسية في الأدبيات التريوية المعاصرة؟ r - ما الإطار النظري لمعايير السياق المؤسسي في الأدبيات التريوية المعاصرة؟ r- الكشف عما إذا كان هناك فروق ذات دلالة إحصائية في استجابات أفراد عينة الدراسة لارجة أهمية اختيار قادة المدارس بالمرحلة الثانوية بمحافظة حفر الباطن في ضوء معائه إدايير السياق المؤسسي تعزى لمتغيرات الدراسة: (النوع الاجتماعي، المؤهل العلمي، المسمى لإيه الوظيفي، سنوات الخدمة)؟ ع - ما التصور المقترح لتظوير نظام اختيار قادة المدارس بالمرحلة الثانوية بمحافظة حفر الباطن في ضوء معايير السياق المؤسسي؟

أهداض الداراسة:

يكمن هدف الدراسة الرئيس في: التعرف على كيفية تطوير اختيار قادة المدارس بالمرحلة الثانوية بمحافظة حفر الباطن في ضوء معايير السياق المؤسسي. 
ولتحقيق الهدف الرئيس يتفرع منه الأهداف الفرعية الآتية: 1 - تحديد الإطار النظري لأساليب اختيار القيادات المدرسية في الأدبيات التريوية المعاصرة. r - تحديد الإطار النظري لمعايير السياق المؤسسي في الأدبيات التربوية المعاصرة.

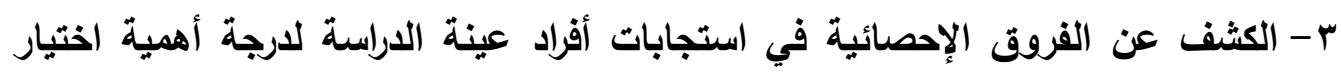
قادة المدارس بالمرحلة الثانوية بمحافظة حفر الباطن في ضوء معايير السياق المؤيس فيسي تعزى لمتغيرات الدراسة: (النوع الاجتماعي، المؤهل العلمي، المسىى الوظيفي، سنوات (الخدمة). ع - بناء التصور المقترح لتطوير اختيار قادة المدارس بالمرحلة الثانوية بمحافظة حفر الباطن في ضوء معايير السياق المؤسسي.

\section{أهمية اثلداساسة}

تتمثل أبرز جواتب أهمية الدراسة الحالية من الناحيتين العلمية، والعملية في الآتي: - الأهمية العلمية (النظرية): ترجع هذه الأهمية إلى الآتي: مواكبة الدراسة لتوجهات وخطط التنمية، والمتمثلة في وروئية المملكة العربية السعودية الإلهية

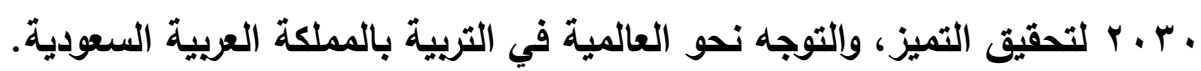

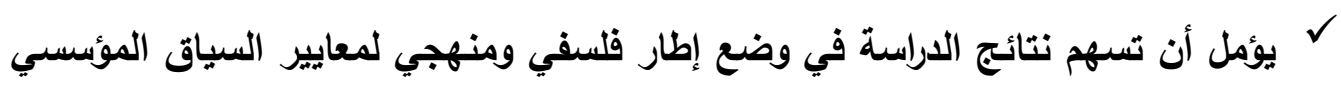
عند اختيار قادة المدارس الثانوية. ل يؤمل أن تشكل الدراسة إضافة علمية للمكتبة التريوية السعودية والعربية بما قد يحتاجه الأدب التربوي في المملكة العربية السعودية، والمنطقة العربية. -الأهمية العملية (التطبيقية): ترجع هذه الأهمية إلى النقاط الآتية: يؤمل أن تسهم نتائج الدراسة الحالية في تقديم صورة واقعية لكيفية اختيار قادة المدارس الإسلة المئس في المرحلة الثانوية بالمملكة العربية السعودية.

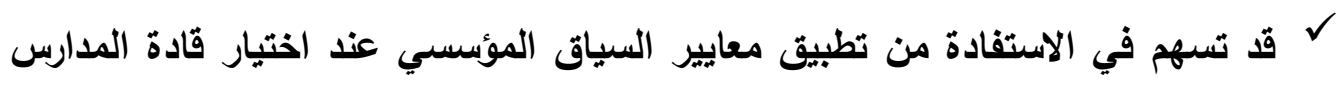
الثانوية في المملكة العربية السعودية. ل قد تساعد الدراسة في تضييق الفجوة بين ما يتم اختيار قادة المدارس حاليا، وما ينبغي أن يتم اختيارهم في ضوء معايير السياق المؤسسي. 
ل يؤمل أن تسهم الاراسة الحالية في فتح مجالات جديدة أمام الباحثين لإجراء أبحاث ودراسات مستقبلية في المؤسسات التعليمية السعودية والعربية.

\section{حلدود الدباسة2:}

تتعين أبعاد الدراسة الحالية، ونطاق معالجتها، وخط سيرها نحو غايتها المأمولة في الددود الآتية: الحدود الموضوعية: اختيار قادة المدارس بالمرحلة الثانوية بمحافظة حفر الباطن في ضوء معايير السياق المؤسسي (الصياغة الاستراتيجية -الروئة والرسالة والأهداف-، التحليل البيئي، الصفات المهنية، العلاقات الإنسانية، الاتصال القيادي، التقويم الإداري). الحدود البشرية: معلمي ومعلمات ووكلاء ووكيلات وقادة وقائدات المدارس الثانوية. الحدود المكانية: محافظة حفر الباطن. الحدود الزمانية: تم تطبيق هذه الدراسة في نهاية الفصل الدراسي الأول ويداية الفصل

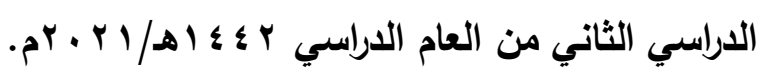

|المصطاحات:

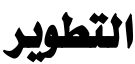
طَوَّرَ : فعل

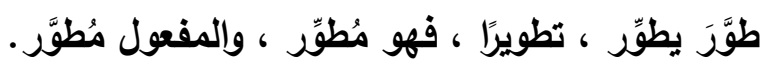

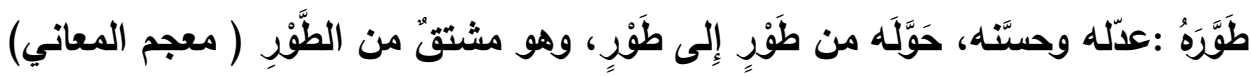

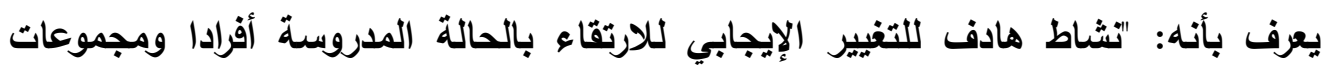

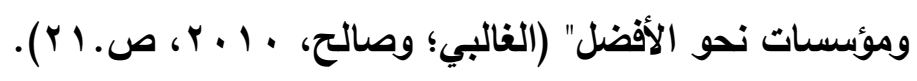

ويعرف الباحثان بأنه: عملية التعديل والتحسين في عملية اختيار قادة مدارس المرحلة الثانوية بمحافظة حفر الباطن في المملكة العربية السعودية وفق معايير السياق المؤسسي.

الاخثبار

إختيار :اسم، إختيار : مصدر اختار

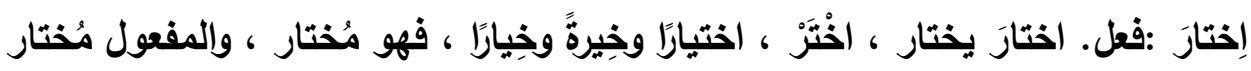




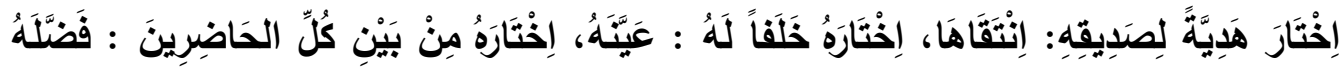

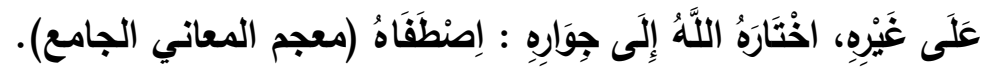
ويعرف بأنه: "العملية التي تخطط لها إدارة القوى البشرية في المؤسسة والتحري عن الموظفين ذوي الكفاءة والتميز لشغل الوظائف الثاغرة والمعلن عنها في المؤسسة والمفاضلة بينهز على أسس ومعايير علمية وسليمة وواضحة ويما يتوافق مع شروط الوظيفة الشاغرة

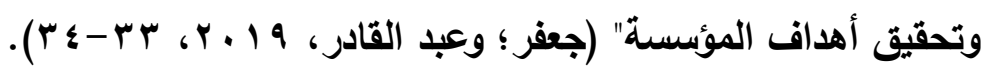
ويعرف الباحثان الاختيار بأنه: عملية انتقاء قادة المدارس الثانوية بمحافظة حفر الباطن بالمملكة العربية السعودية وفق معايير السياق المؤسسي.

الميميار مِعيار :اسم

الجمع : معايِيرُ، المِعَيَرُر : العِيارُ

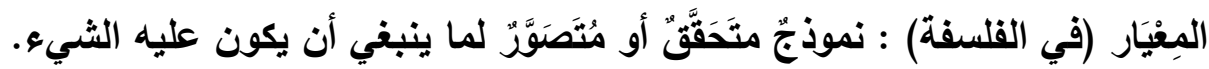
عيار؛ مقياسُ يُقاسُ به غيرُه للحكم والتَّقيّم ( معجم المعاني الجامع) ويعرف بأنه: "مقاييس وقواعد منظمة للقيام بالأثياء، وهي الخطوط العامة التي يرجع إليها أصحاب القرار والعاملين في المؤسسات التعليمية لرفع جودة أدائها وعملها (مشعلة، $\cdot(r \cdot 1 \mathrm{~V}$

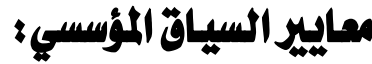

ويعرفها الباحثان بأنها: "مجموعة المعايير التي تخص قادة مدارس المرحلة الثانوية بمحافظة حفر الباطن بالمملكة العربية السعودية والتي تثمل: الصياغة الاستراتيجية، والتحليل البيئي، والصفات المهنية، والعلاقات الإنسانية، والاتصال القيادي، والتقويم الإداري.

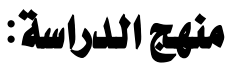

في ضوء طبيعة الاراسة، والأهداف التي تسعى الدراسة لتحقيقها، والأسئلة التي تحاول الدراسة الإجابة عليها، والبيانات المراد الحصول عليها، فإن هذه الاراسة ستستخدم المنهج الوصفي بنوعيه المسحي والتطويري، وذلك لوصف وتحليل المشكلة موضوع الدراسة، وجمع الحقائق والأدلة، ووصف الظروف الخاصة بها، وما يستلزمه ذلك من الكشف عن العلاقات 
بين أبعادها من خلال جمع الوثائق والدراسات المعاصرة المتوافرة وتحليلها كما وكيفا، بصورة

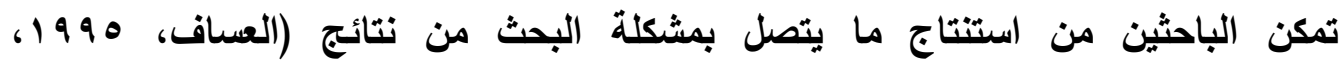

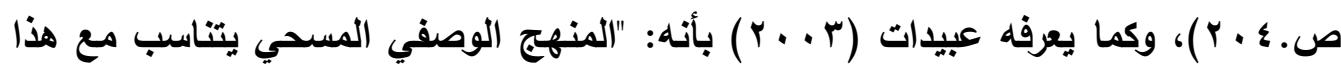

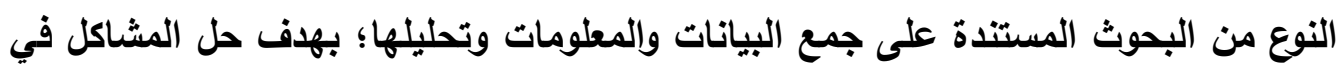
الواقع أو التعرف على حقيقة تلك المشاكل، والوصول إلى نتائج علمية مقبولة، الأمر الذي

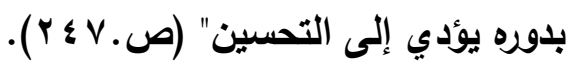

$$
\begin{aligned}
& \text { مجتمع الدداسة }
\end{aligned}
$$

بحسب موضوع الاراسة أنها ستتناول اختيار قادة المدارس بالمرحلة الثانوية بمحافظة حفر الباطن في ضوء معايير السياق المؤسسي، فإن مجتمع الاراسة سيكون جميع معلمي

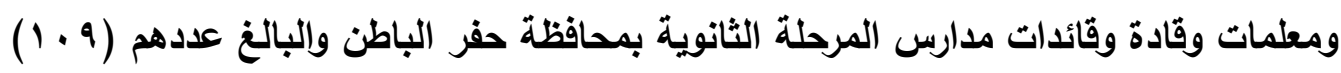

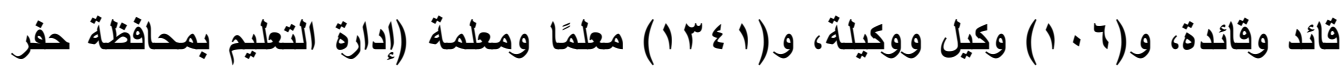

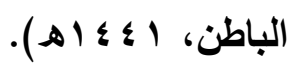

ثينة الدارسة

نظراً لطبيعة الدراسة الحالية، ولغاية تحقيق أهدافها، وما يتطلبه من إجراءات، قام الباحثان

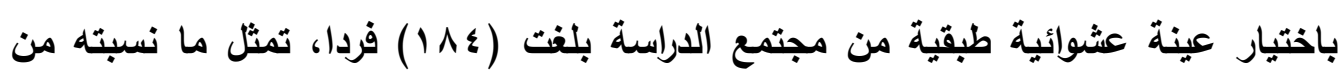
مجتمع البحث (ع ا 1\%).

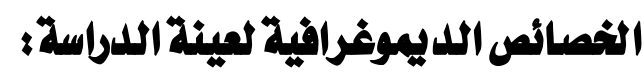

تتصف عينة الاراسة بعدد من الخصائص الايموغرافية لأفرادها، وفيما يأتي تفصيل ذلك:

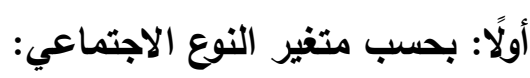




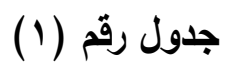

\begin{tabular}{|c|c|c|}
\hline النسبة \% & العدد & الاجتماعي النوع \\
\hline 14.7 & 27 & ذكور \\
\hline 85.3 & 157 & إناث \\
\hline 100.0 & 184 & المجموع \\
\hline
\end{tabular}

يتبين من الجدول رقم (1) أن أفراد العينة من الذكور بلغ عددهم (YV) فردا، وينسبة

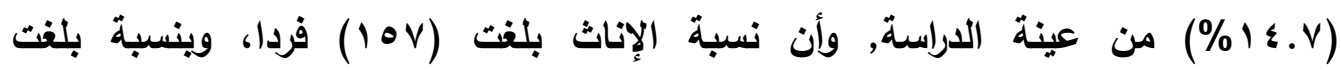

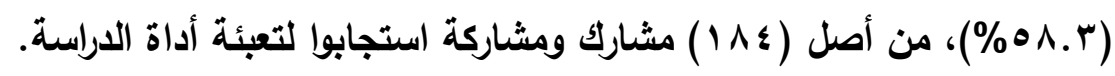

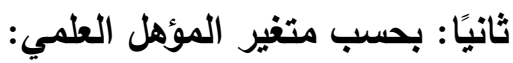

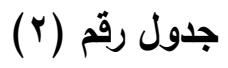

\begin{tabular}{|c|c|c|}
\hline النسبة \% & العدد & المؤهل العلمي \\
\hline 91.3 & 168 & بكالوريوس \\
\hline 8.7 & 16 & أعلى من \\
\hline 100.0 & 184 & المجموع \\
\hline
\end{tabular}

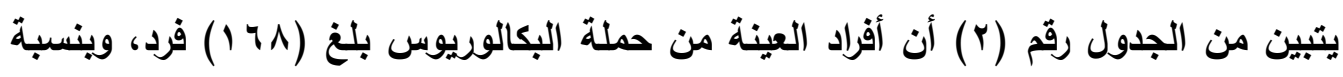

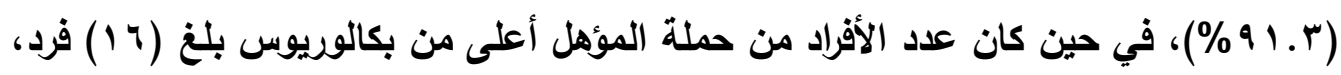
وينسبة (\%^.v) 
ثالثأ : بحسب متفير المسمى الوظيفي:

جدول رقم (r)

\begin{tabular}{|c|c|c|}
\hline النسبة \% & العدد & المسيفى \\
\hline 60.9 & 112 & معلم//ة \\
\hline 10.9 & 20 & وكيد/ة \\
\hline 28.3 & 52 & قائد/ة \\
\hline 100.0 & 184 & المجموع \\
\hline
\end{tabular}

يتبين من الجدول رقم (r) أن أفراد العينة من المعلمين والمعلمات بلغ (Y I I) فرد، وينسبة

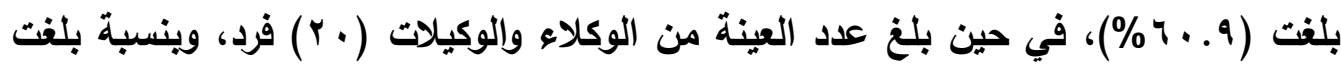
(9. ( ا\%)، في حين بلغ عدد المستجيبين من قادة وقائدات المدارس الثانوية (به) فردا بنسبة. (28.3\%) رابعًاء بحسب مثفير سنوات الثلدمة:

جدول رقم (ع)

وصف أفراد العينة بحسب متغير المسمى الوظيفي

\begin{tabular}{|c|c|c|}
\hline النسبة \% & العدد & سنوات الخدمة \\
\hline 22.8 & 42 & سنول من \\
\hline 33.7 & 62 & ه- . 1 سنوات \\
\hline 28.3 & 52 & ||-0 سنة \\
\hline 15.2 & 28 & أكثر من 10 \\
\hline 100.0 & 184 & المجموع \\
\hline
\end{tabular}


يتبين من الجدول رقم (؟) أن أفراد العينة الأين سنوات خبرتهم أقل من خمس سنوات بلغت

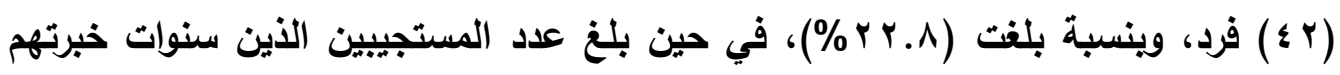

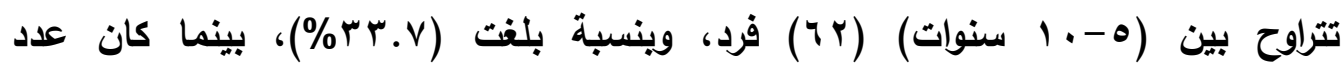
المستجيبين الذي تتراوح سنوات خبرته بين (11-10 سنة) (roه) فرد، وينسبة بلغت

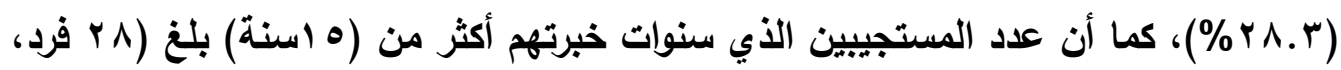

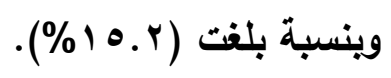

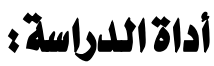

استخدمت الدراسة الاستبانة: وهي عبارة عن مجموعة من العبارات، أو الأسئلة المكتوية،

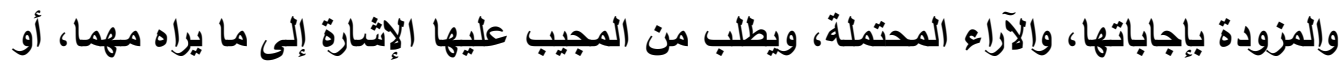

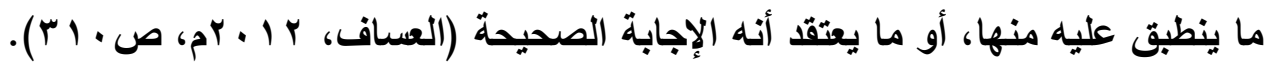
وللحصول على بيانات الاراسة الحالية تم استخدام الاستبانة كأداة لجمع البيانات، وقد اتبع الاجه الباحثان الخطوات الآتية في إعداده: 1 - تحديد الهدف من الاستبيان: تشخيص واقع اختيار قادة المدارس بالمرحلة الثانوية بمحافظة حفر الباطن في ضوء معايير السياق المؤسسي. r - تحديد محتوى الاستبيان: تكون الاستبيان من ستة مجالات (الصياغة الاستراتيجية -

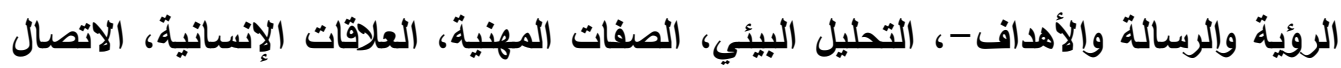
القيادي، التقويم الإداري)؛ وتم صياغة فقرات الأداة وفقًا للأدبيات المتوافرة من خلال الاعتماد

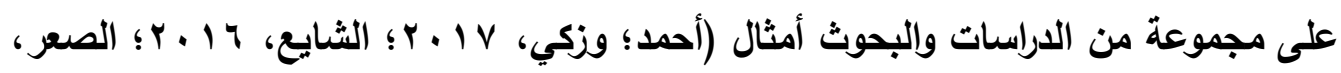

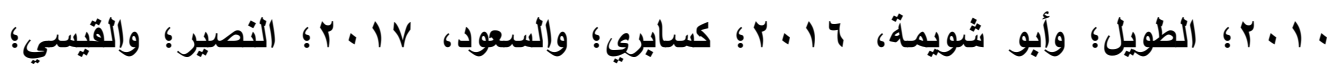

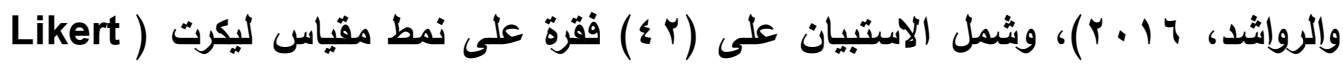
(Scale متدنية جدا.

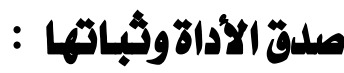

- صدق المحكمين: للتحقق من صدق الاستبيان قام الباحثان بعرضه على خمسة محكمين تخصص إدارة وتخطيط تريوي، ولغة عربية، وقياس وتقويم؛ بغرض التأكد من أن الفقرات 


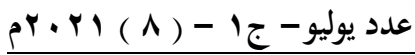

تصور مقترح لتطوير م...

تعبر عن المجال الذي اندرجت تحته، ومدى الصحة اللغوية للفقرات، وتم أخذ جميع آراء المحكمين من حذف وإضافة وتعديل، وفي ضوء آراء المحكمين أصبح الاستبيان مكون من

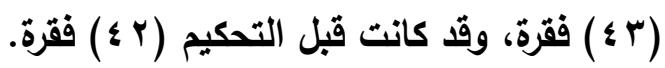
- الصدق البنائي: يعتبر الصدق البنائي أحد مقاييس صدق الأداة الذي يقيس تحقق الأهداف التي تريد الأداة الوصول إليها، ويبين مدى ارتباط كل مجال من مجالات أداة الدراسة بالدرجة الكلية لفقرات الأداة، وللتحقق من الصدق البنائي تم حساب معاملات الارتباط بين درجة كل مجال من مجالات أداة الدراسة والدرجة الكلية للاستبيان كما في الجدول رقم (ه).

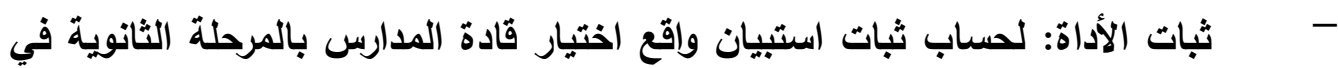
محافظة حفر الباطن في ضوء معايير السياق المؤسسي، استخدم الباحثان طريقة ألفات

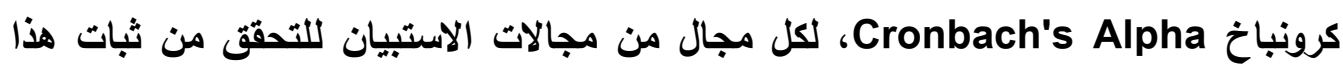
المجالات، والجدول رقم (•) يوضح ذلك.

جدول رقم (0)

معامل الارتباط بين درجة كل مجال من مجالات أداة الدراسة والدرجة الكلية للأداة، ودرجة ثبات معامل ألفا كرونباخ لكل مجال من مجالات أداة الاراسة، والدرجة الكلية للأداة

\begin{tabular}{|c|c|c|c|c|}
\hline $\begin{array}{l}\text { معامل ألقا } \\
\text { Alpha }\end{array}$ & $\begin{array}{c}\text { معامل الارتباط } \\
\text { R)) }\end{array}$ & الفقرات & المجال & b \\
\hline 0.98 & $.855^{* *}$ & 9 & الصياغة الاستراتيجية -الروئية والرسالة & 1 \\
\hline 0.96 & $.903 * *$ & 8 & التحليل البيئي & 2 \\
\hline 0.96 & $.918 * *$ & 7 & الصفات المهنية & 3 \\
\hline 0.95 & $.895 * *$ & 6 & العلاقات الإنسانية & 4 \\
\hline 0.96 & $.924^{* *}$ & 6 & الاتصال القيادي & 5 \\
\hline 0.97 & $.936 * *$ & 7 & التقويم الإداري & 6 \\
\hline 0.99 & & 43 & إجمالي الأداة ككل & \\
\hline
\end{tabular}

دالة عند مستوى دلالة (1 (...). 


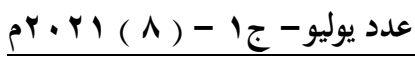

تصور مقترح لتطوير ...

يتضح من الجدول رقم (0) أن جميع معاملات الارتباط في جميع مجالات الاستبيان دالة إحصائيًا، ويدرجة قوية عند مستوى دلالة (1 ...)، ويذلك تعتبر جميع مجالات الاستبيان صادقة و تقيس ما وضعت لقياسه. كما يتبين من الجدول رقم (0) أن درجة ثبات المجالات تراوحت بين (90.9 .91. . •)، كما أظهرت نتائج التحليل أن ثبات الأداة ككل وصل إلى (99. . .)، الأمر الذي يعكس درجة داته عالية من الثبات.

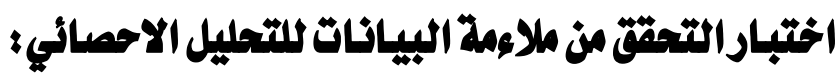

لأغراض التحقق من موضوعية نتائج الاراسة تم إجراء اختبار كولمجروف وسميرنوف (Kolmogorov- Smirnov)، وذللك للتحقق من خلو بيانات البحث من المشكلات الاحصائية التي قد تؤثر سلباً على نتائج اختبارات الفروق في المتفيرات الايموغرافية للاراسة، ويشترط هذا الاختبار توافر التوزيع الطبيعي في البيانات. والجدول رقم (6) يوضح ذلك:

جدول رقم (†) التوزيع الطبيعي لمتغيرات الدراسة

\begin{tabular}{|c|c|c|c|c|}
\hline النتيجة & مستوى & $\begin{array}{c}K-\mathbf{S} \\
(Z)\end{array}$ & المعاييز & م \\
\hline تتبع التوزيع الطبيعي & .335 & .8210 & الصياغة الاستراتيجية -الروئية & 1 \\
\hline تتبع التوزيع الطبيعي & .060 & 1.358 & التحليل البيئي & 2 \\
\hline تتبع التوزيع الطبيعي & .208 & 1.064 & الصفات المهزية & 3 \\
\hline تتبع التوزيع الطبيعي & .224 & 1.045 & العلاقات الإنسانية & 4 \\
\hline تتبع التوزيع الطبيعي & .153 & 1.144 & الاتصال القيادي & 5 \\
\hline تتبع التوزيع الطبيعي & .485 & .837 & التقويم الإداري & 6 \\
\hline تتبع التوزيع الطبيعي & .215 & 1.565 & \multicolumn{2}{|l|}{ معايير السياق المؤسسي ككل } \\
\hline
\end{tabular}




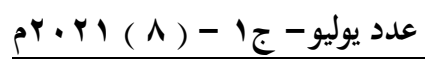

تصور مقترح لتطوير

يتبين من الجدول رقم (6) أن جميع المعايير، إضافة إلى معايير السياق المؤسسي ككل كانت نسب التوزيع الطبيعي لها أكثر من (0.05)، وهو المستوى المعتمد في المعالجة الاحصائية لهذه الاراسة. كما يتضح من الجدول رقم () أن قيمة الدلالة لاختبار التوزيع الطبيعي للمعايير السياق المؤسسي تراوحت بين (0.485 -0.060)، إضافة إلى الأداة ككل حيث كاتت مستوى

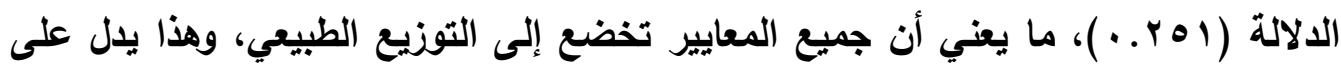

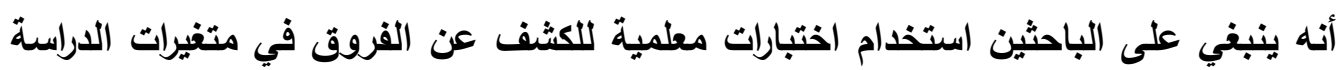

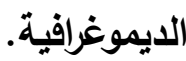

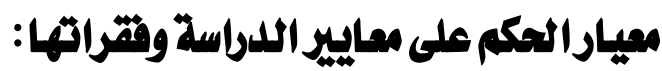

تبنى الباحثان معيارا للحكم على مجالات وفقرات الدراسة كالآتي: وقد تم إيجاد حدود كل بليل من خلال :

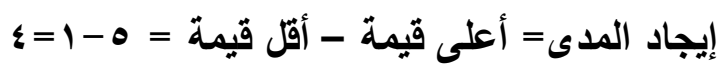

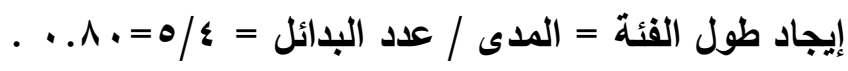

(v) جدول رقم

معيار الحكم في معايير الدراسة وفقراتها

\begin{tabular}{|c|c|c|c|}
\hline \multirow{2}{*}{ الالالة اللفظية } & \multicolumn{2}{|c|}{ الحدود الحقيقية للمتوسط الحسابي } & \multirow{2}{*}{ قيمة البديل } \\
\hline & الحد الأعلى & الحد الأدنى & \\
\hline متدنية جدا & 1.80 & 1 & 1 \\
\hline 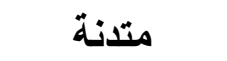 & 2.60 & 1.81 & 2 \\
\hline متوسطة & 3.40 & 2.61 & 3 \\
\hline عالية & 4.20 & 3.41 & 4 \\
\hline عالة جدا & 5 & 4.21 & 5 \\
\hline
\end{tabular}




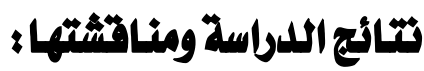

قام الباحثان بالإجابة عن أسئلة الدراسة من خلال تحليل البيانات، والتركيز على أعلى فقرة،

وأدنى فقرة، وتفسير نتائجهما.

الإجابة عن السؤال الأول:

ما درجة أهمية اختيار قادة المدارس بالمرحلة الثانوية بمحافظة حفر الباطن في ضوء معايير

السياق المؤسسي؟

للإجابة عن ذلك تم استخدام المتوسطات الحسابية، والانحرافات المعيارية التي تقيس درجة

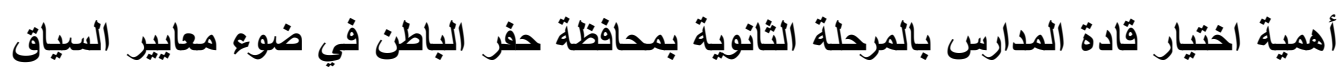
المؤسسي، وتم عرض النتائج على النحو الآتي:

جدول رقم (^)

المتوسطات الحسابية والانحرافات المعيارية لتقديرات أفراد العينة لارجة أهمية اختيار قادة

المدارس بالمرحلة الثانوية بمحافظة حفر الباطن في ضوء معايير السياق المؤسسي

\begin{tabular}{|c|c|c|c|c|c|}
\hline درجة أهمية & الانحراف & المثتوسط & الرتبة & معايير السياق المؤسسي & b \\
\hline عالية & 1.121 & 3.67 & 6 & الصياغة الاستراتيجية -الروئية & 1 \\
\hline عالية & 1.028 & 3.81 & 4 & التحليل البيئي & 2 \\
\hline عالية & .921 & 4.03 & 3 & الصفات المهنية & 3 \\
\hline عالية & .931 & 4.14 & 1 & العلاقات الإنسانية & 4 \\
\hline عالية & .942 & 4.09 & 2 & الاتصال القيادي & 5 \\
\hline عالية & 1.011 & 3.80 & 5 & التقويم الإداري & 6 \\
\hline عالية & .897 & 3.92 & & متوسط المعايير ككل & \\
\hline
\end{tabular}

يتضح من الجدول رقم (8) الآتي: إن درجة أهمية اختيار قادة المدارس بالمرحلة الثانوية بمحافظة حفر الباطن في ضوء معايير السياق المؤسسي قات جاءت بلدرجة أهيه أهمية 
بدلالة لفظة (عالية)، حيث بلغ المتوسط لمعايير السياق المؤسسي ككل (3.92)، و بانحراف معياري (0.897)، ويعزو الباحثان هذه النتيجة إلى حرص القائمين على إدارة التعليم بمحافظة حفر الباطن في اختيار وتعيين القيادات المدرسية. كما يتضح من الجدول رقم (8) أن درجة أهمية اختيار قادة المدارس بالمرحلة الثانوية بمحافظة حفر الباطن في ضوء معايير السياق المؤسسي على مستوى المعايير، حيث تم ترتيبها تنازلياً حسب المتوسط الحسابي، ثم الانحراف المعياري لكل معيار كما يلي: ا. حصل معيار العلاقات الإنسانية على المرتبة الأولى، ويدرجة أهمية دلالة لفظية (عالية)، حيث بلغ المتوسط الحسابي (4.14)، و بانحراف معياري ( 1 (14.931). r. حصل معيار الاتصال القيادي على المرتبة الثانية، ويلرجة أهمية بدلالة لفظية (عالية)، حيث بلغ المتوسط الحسابي (4.03)، و بانحراف معياري (0.942). r. حصل معيار الصفات المهنية على المرتبة الثالثة، ويدرجة أهمية بلالة لفظية (عالية)، حيث بلغ المتوسط الحسابي (3.81)، بانحراف معياري (0.921).

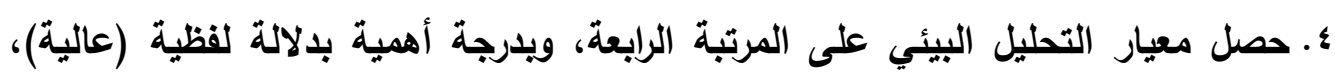
حيث بلغ المتوسط الحسابي (3,81)، إضافة إلى تباين واضح في استجابات أفراد العينة حول هذا المعيار من خلال درجة الانحراف المعياري البالغة (1,028). ه. حصل معيار التقويم القيادي على المرتبة الخامسة، ويدرجة أهمية بدلالة لفظية (عالية)، حيث بلغ المتوسط الحسابي (3.80) إضافة إلى تباين واضح في استجابات أفراد العينة حول

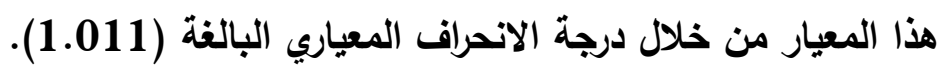

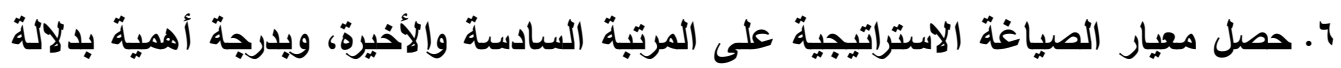
لفظية (عالية)، حيث بلغ المتوسط الحسابي (3,67)، إضافة إلى تباين واضح في استجابات

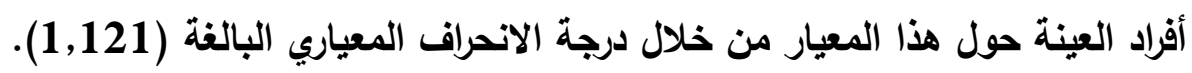




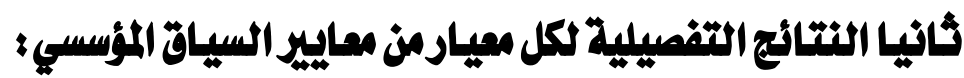

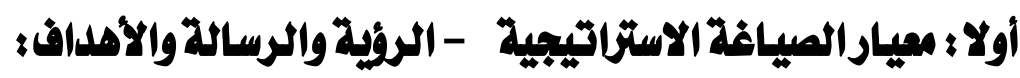

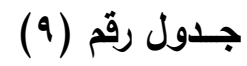

المتوسطات الحسابية والاتحرافات المعيارية لتقديرات أفراد العينة لارجة أهمية اختيار قادة المدارس بالمرحلة الثانوية بمحافظة حفر الباطن في ضوء معايير السياق المؤسسي

(الصياغة الاستراتيجية) - (الصية)

\begin{tabular}{|c|c|c|c|c|c|}
\hline 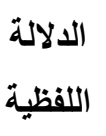 & 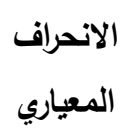 & المستوسط & 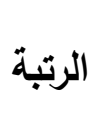 & معيار الصياغة الاستراتيجية & م \\
\hline عالية & 1.193 & 3.83 & 2 & والمدرسة. روية واضحة تعبر عما تطمح إليه & 1 \\
\hline عالية & 1.092 & 3.93 & 1 & وضع رسالة تحدد المهام لتحقيق الروئية. & 2 \\
\hline عالية & 1.367 & 3.47 & 8 & الثدراك جميع المستفيدين في صياغة استراتيجية & 3 \\
\hline عالية & 1.234 & 3.75 & 3 & مراجعة رسالة المدرسة بشكل دوري بما يتناسب & 4 \\
\hline عالية & 1.300 & 3.62 & 7 & استخدام الرسالة كمرجع لاتخاذ القرارات المدرسية. & 5 \\
\hline عالية & 1.315 & 3.41 & 9 & تعيين فريق لترجمة رسالة المدرسة بما يؤدي إلى & 6 \\
\hline عالية & 1.297 & 3.68 & 4 & تالمستقبل الأهداف الاستراتيجية لمجالات التطوير & 7 \\
\hline 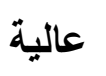 & 1.231 & 3.66 & 5 & صياغة أهداف استراتيجية بطريقة يمكن قياسها. & 8 \\
\hline 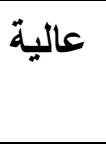 & 1.258 & 3.66 & 6 & 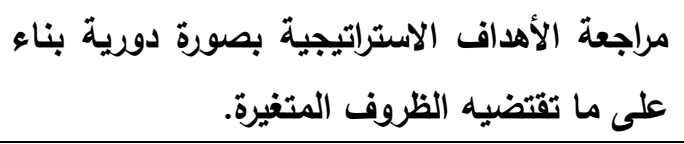 & 9 \\
\hline عالية & 1.121 & 3.67 & & متوسط معيار الصياغة الاستراتيجية ككل & \\
\hline
\end{tabular}


يتضح من الجدول رقم (9 ) الآتي: إن درجة أهمية اختيار قادة المدارس بالمرحلة الثانوية

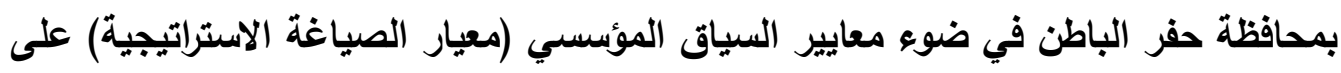
واقع تطبيق بدلالة لفظية (عالية)، حيث بلغ المتوسط الحسابي (Y.TV)، إضافة إلى تباين

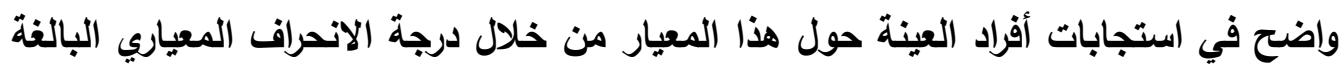
(1 I I I )، ويعزو الباحثان هذه النتيجة إلى الآتي: ضرورة اتباع أساليب حديثة في اختيار وتعيين القيادات المدرسية بالمرحلة الثانوية. أما درجة أهمية اختيار قادة المدارس بالمرحلة الثانوية بمحافظة حفر الباطن في ضويو معايير السياق المؤسسي (معيار الصياغة الاستراتيجية) على مستوى فقرات هذا المعيار فإنه يتضح من الجدول رقم (V) الآتي: - عصول الفقرة رقم (r) والتي تتص على أن "وضع رسائة تحدد المهام لتحقيق الروئة"

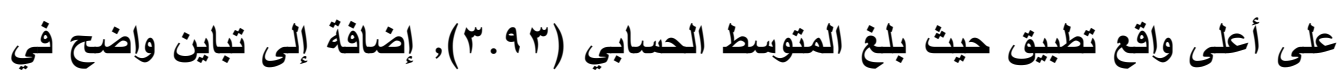

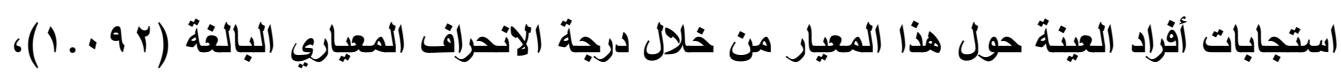

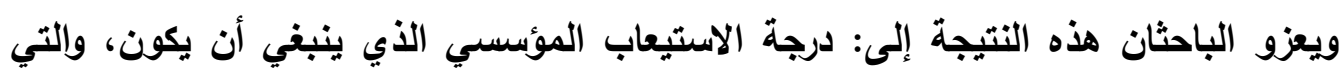
تنبع من روح الرسالة التربوية. - حصلت الفقرة رقم (†) والتي تنص على "تعيين فريق لترجمة رسالة المدرسة بما يؤدي إلى تحقيق روئيتها" على أدنى واقع جودة بمتوسط حسابي بلغ (اءـــ)، إضافة إلى تباين

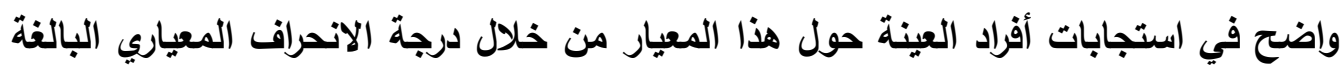

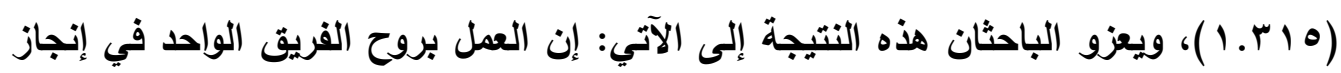

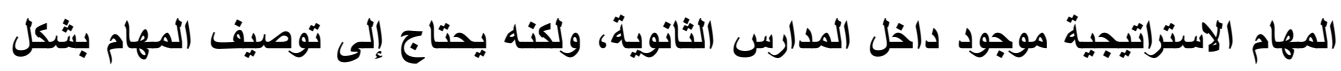
دقيق. 


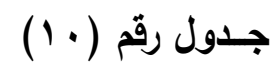

ثانيا ؛ معيار التحايل البيئي؛

المتوسطات الحسابية والانحرافات المعيارية لتقديرات أفراد العينة لدرجة أهمية اختيار قادة المدارس بالمرحلة الثانوية بمحافظة حفر الباطن في ضوء معايير السياق المؤسسي

(التحليل البيئي)

\begin{tabular}{|c|c|c|c|c|c|}
\hline اللفظية & الانحراف & | الحستوسط & الرتبة & معيار التحليل البيئي & b \\
\hline 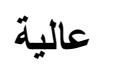 & 1.081 & 3.92 & 3 & رصد التغيرات المتسارعة في بيئة التعليم. & 1 \\
\hline عالية & 1.169 & 4.00 & 1 & توظيف تقتيات التعليم الحديثة في العملية & 2 \\
\hline عالية & 1.238 & 3.67 & 7 & 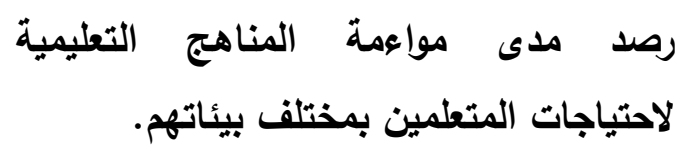 & 3 \\
\hline عالية & 1.294 & 3.70 & 6 & 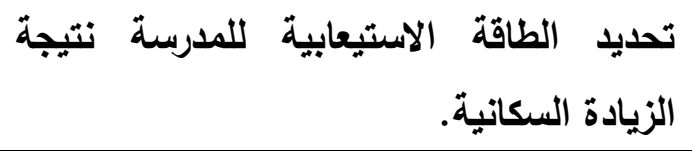 & 4 \\
\hline عالية & 1.133 & 3.87 & 4 & الالتزام باتباع الأساليب الحديثة في القيادة & 5 \\
\hline عالية & 1.223 & 3.55 & 8 & إشراك المجالس المحلية في تسبير بعض & 6 \\
\hline عالية ع & 1.171 & 3.99 & 2 & تدريب المعلمين بغرض تحسين نوعية التعليم. & 7 \\
\hline عالية & 1.158 & 3.78 & 5 & تصميم النظام الداخلي للمدرسة لتحقيق & 8 \\
\hline 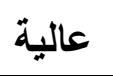 & 1.028 & 3.81 & & متوسط معيار التحليل البيئي ككل & \\
\hline
\end{tabular}

يتضح من الجدول رقم ( • 1) الآتي: إن درجة أهمية اختيار قادة المدارس بالمرحلة الثانوية بمحافظة حفر الباطن في ضوء معايير السياق المؤسسي (معيار التحليل البيئ) على واقع

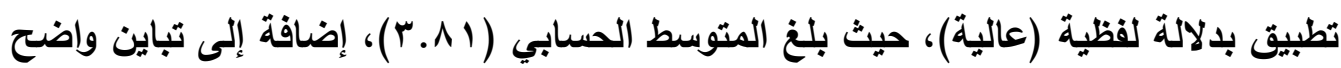


في استجابات أفراد العينة حول هذا المعيار من خلال درجة الانحراف المعياري البالغة

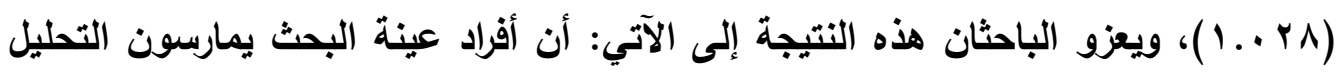

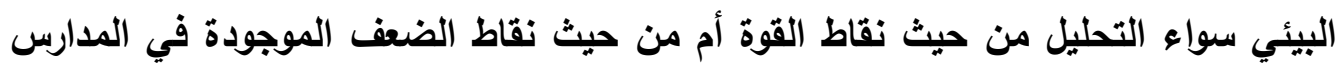
الثانوية، وعليه فقد رأوا بأنه شيع موجود وعليه فقد جاء في أسفل درجة الأهمية.

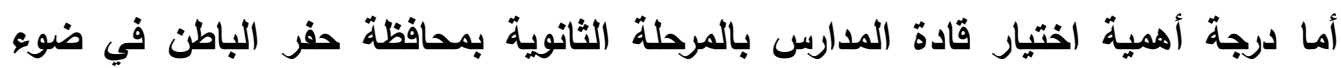
معايير السياق المؤسسي (معيار التحليل البيئي) على مستوى فقرات هذا المعيار فإنه يتضح

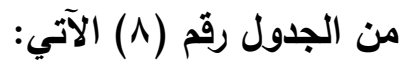
- حصول الفقرة رقم (ץ) والتي تنص على أن "توظيف تقنيات التعليم الحديثة في العملية

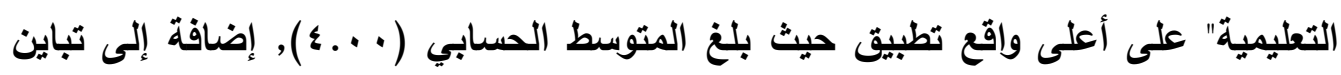
واضح في استجابات أفراد العينة حول هذا المعيار من خلال درجة الانحراف المعياري البالغة

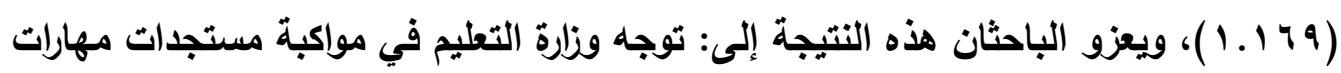
القرن الحادي والعشرين، بما فيها الثقافة الرقمية وتوظيفها في العملية التعليمية.

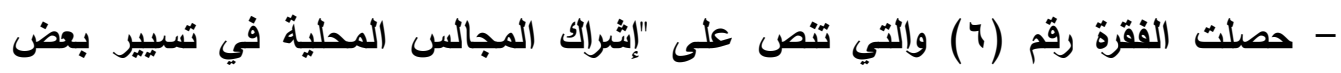
الثؤون الداخلية للمدرسة" على أدنى واقع جودة بمتوسط حسابي بلغ (هـ.ب)، إضافة إلى تباين واضح في استجابات أفراد العينة حول هذا المعيار من خلال درجة الانحراف المعياري

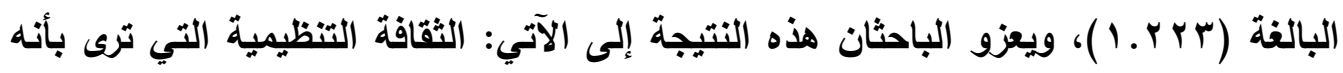
لازالت القيادة المدرسية تتميز بالمركزية في أداء مهامها الإدارية في المدارس الثانوية. ثالثا: معيار الصفات المهنية: 


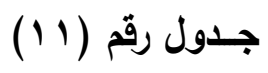

المتوسطات الحسابية والانحرافات المعيارية لتقديرات أفراد العينة لواقع اختيار قادة المدارس بالمرحلة الثانوية بمحافظة حفر الباطن في ضوء معايير السياق المؤسسي (الصفات المهنية)

\begin{tabular}{|c|c|c|c|c|c|}
\hline اللالالة & الانحراف المعياري & المتوسط & الرتبة & معيار الصفات المهنية & p \\
\hline عالية & 1.044 & 4.05 & 4 & الاتصاف بالولاء للعمل القيادي. & 1 \\
\hline 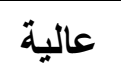 & 1.043 & 4.15 & 2 & التفاني في إنجاز الأعمال. & 2 \\
\hline 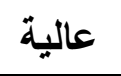 & 1.063 & 4.11 & 3 & معالجة المشاكل المدرسية. & 3 \\
\hline عالية & .984 & 4.22 & 1 & الالتزام بحدود مسؤوليته. & 4 \\
\hline عالية & 1.196 & 3.86 & 6 & استخدام السلطة دون تعسف. & 5 \\
\hline 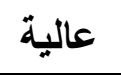 & 1.162 & 3.85 & 7 & تجنب الاستئثار بامتيازات العمل القيادي. & 6 \\
\hline 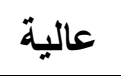 & 1.018 & 3.97 & 5 & القدرة على التأثير في الآخرين. & 7 \\
\hline عالية ع ع & .921 & 4.03 & & متوبط معيار الصفات المهنية ككل & \\
\hline
\end{tabular}

يتضح من الجدول رقم (11) الآتي: إن واقع اختيار قادة المدارس بالمرحلة الثانوية بمحافظة حفر الباطن في ضوء معايير السياق المؤسسي (معيار الصفات المهنية) على واقع باتع تطبيق بدلالة لفظية (عالية)، حيث بلغ المتوسط الحسابي (r...؛)، و بانحراف معياري

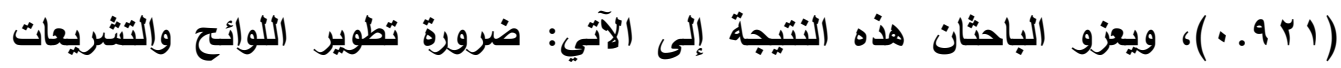
النظامية، بما يحقق الثفافية والمصداقية في عملية اختيار القيادات المدرسية الثانوية. أما واقع اختيار قادة المدارس بالمرحلة الثانوية بمحافظة حفر الباطن في ضوء معايير السياق المؤسسي (معيار الصفات المهنية) على مستوى فقرات هذا المعيار فإنه يتضح من لـن الجدول رقم (11) - الآتي: - - مصول الفقرة رقم (؟) والتي تنص على أن "الالتزام بحدود مسؤوليته" على أعلى

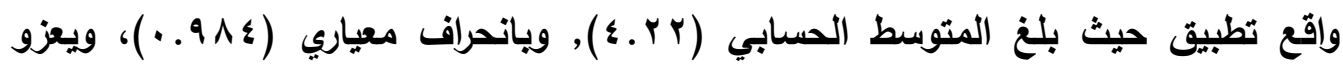


الباحثان هذه النتيجة إلى: الاهتمام بالعمل المؤسسي من خلال تحديد المهام والأدوار القيادية والإدارية لاى القيادات المدرسية الثانوية. حصلت الفقرة رقم (؟) والتي تنص على "تجنب الاستئثار بامتيازات العمل القيادي" على أدنى واقع جودة بمتوسط حسابي بلغ (هی (ب)، إضافة إلى تباين واضح في استجابات أفراد العينة

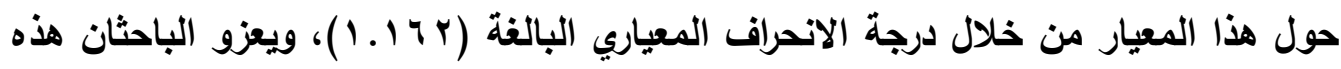
النتيجة إلى الآتي: الثقافة التظيمية السائدة في المدارس الثانوية وأنه ينبغي على القيادات تفعيل التمكين القيادي في المدرسة. كابعاء معيارالملاقتاثة الإنسانية:

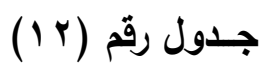

المتوسطات الحسابية والانحرافات المعيارية لتقديرات أفراد العينة لواقع اختيار قادة المدارس بالمرحلة الثانوية بمحافظة حفر الباطن في ضوء معايير السياق المؤسسي (العلاقات (الإنسانية)

\begin{tabular}{|c|c|c|c|c|c|}
\hline اللالالة & الانحراف & الحسوسط الحسب & 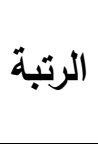 & معيار العلاقات الإنسانية & م \\
\hline عالية & 1.017 & 4.22 & 2 & احترام خصوصية الآخرين. & 1 \\
\hline عالية & 1.077 & 4.16 & 3 & الآختخدام كلمات إيجابية في التعامل مع & 2 \\
\hline 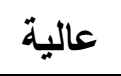 & 1.144 & 4.09 & 5 & دعم التطور المهني للعاملين في المدرسة. & 3 \\
\hline عالية ع ع & 1.084 & 4.16 & 4 & التحدث بطريقة إيجابية عن الزملاء. & 4 \\
\hline 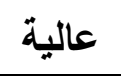 & 1.208 & 3.84 & 6 & العدالة في توزيع الأعمال. & 5 \\
\hline عالية & 1.003 & 4.35 & 1 & المحافظة على سرية بيانات العاملين. & 6 \\
\hline 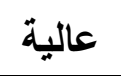 & .931 & 4.14 & & متوسط معيار العلاقات الإنسانية ككل & \\
\hline
\end{tabular}


يتضح من الجدول رقم (r l ) الآتي: إن واقع اختيار قادة المدارس بالمرحلة الثانوية بمحافظة

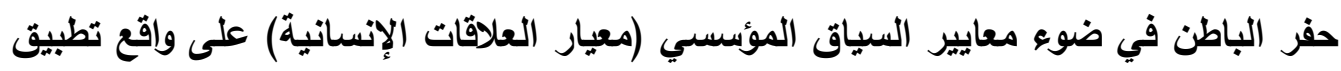

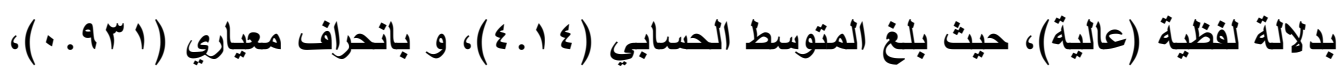
ويعزو الباحثان هذه النتيجة إلى الآتي: الاعتقاد السائد أن من يعتثق مهنة التربية فهو رسول بقدوته، ومثاله وصفاته، وأخلاقه الحميدة والتي تدفع بالفرد إلى الإخلاص والتفاني في التي عمله.

أما واقع اختيار قادة المدارس بالمرحلة الثانوية بمحافظة حفر الباطن في ضوء معايير

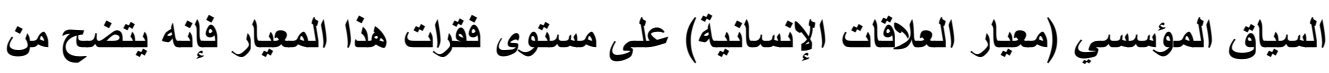
الجدول رقم (Y I) الآتي: - حصول الفقرة رقم (؟ ) والتي تنص على أن "المحافظة على سرية بيانات العاملين" على الانى

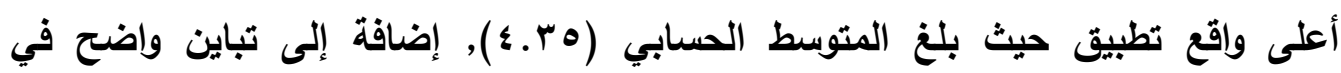
استجابات أفراد العينة حول هذا المعيار من خلال درجة الانحراف المعياري البالغة (ب . . . (1)، ويعزو الباحثان هذه النتيجة إلى: ضرورة تمتع القيادات المدرسية بالصفات الثخصية والتي دلي يأتي على رأسها الأمانة وتحمل المسؤولية. - حصلت الفقرة رقم (ه) والتي تنص على "العدالة في توزيع الأعمال" على أدنى واقع جودة

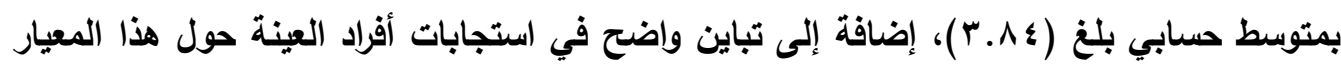

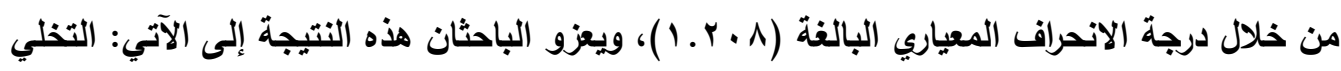

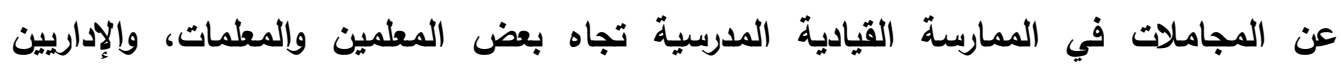

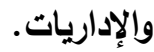




\section{خامسا ؛ معيارالاتثسال القيادي؛}

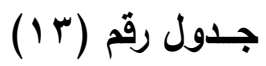

المتوسطات الحسابية والانحرافات المعيارية لتقديرات أفراد العينة لواقع اختيار قادة المدارس بالمرحلة الثانوية بمحافظة حفر الباطن في ضوء معايير السياق المؤسسي (الاتصال (القيادي)

\begin{tabular}{|c|c|c|c|c|c|}
\hline 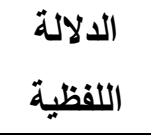 & 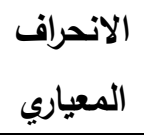 & الحستوسط المسب & 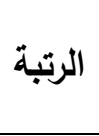 & معيار الاتصال القيادي & b \\
\hline عالية & 1.089 & 4.07 & 4 & المناقشة بمنطق وإيجابية. & 1 \\
\hline عالية & 1.173 & 4.04 & 5 & التحدث بأسلوب متواضع. & 2 \\
\hline عالية & 1.086 & 4.11 & 2 & تجنب إهدار الوقت. & 3 \\
\hline عالية & 1.121 & 4.11 & 3 & تجنب الكلام بغياب الشخص المعني. & 4 \\
\hline عالية & 1.048 & 3.97 & 6 & الاعتماد على الأرقام والحقائق. & 5 \\
\hline عالية جدا & .964 & 4.24 & 1 & 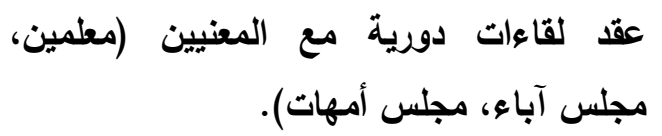 & 6 \\
\hline عالية & .942 & 4.09 & & متوسط معيار الاتصال القيادي ككل & \\
\hline
\end{tabular}

يتضح من الجدول رقم (r I ) الآتي: إن واقع اختيار قادة المدارس بالمرحلة الثانوية بمحافظة حفر الباطن في ضوء معايير السياق المؤسسي (معيار الاتصال القيادي) على واقع تطبيق بدلالة

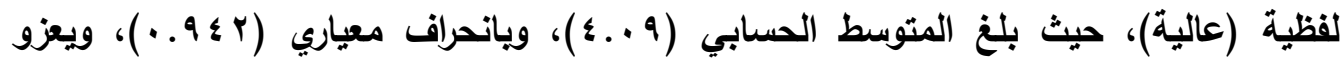
الباحثان هذه النتيجة إلى الآتي: أن المرؤوسين بحاجة إلى شعور القيادات بأوضاعهم المهنية والثخصية، والاحساس بهمم من خلال التواصل الثخصي بهم، وإلعمل على تحفيزهم في لأداء مهامهم. أما واقع اختيار قادة المدارس بالمرحلة الثانوية بمحافظة حفر الباطن في ضوء معايير السياق المؤسسي (معيار الاتصال القيادي) على مستوى فقرات هذا المعيار فإنه يتضح من الجدول رقم

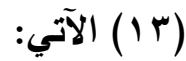
- حصول الفقرة رقم (7) والتي تنص على أن "عقد لقاعات دورية مع المعنيين (معلمين، مجلس آباء، مجلس أمهات)" على أعلى واقع تطبيق حيث بلغ المتوسط الحسابي (؟ ب. ) ), 

تصور مقترح لنطوير ...

و بانحراف معياري (؟ 9 9 · )، ويعزو الباحثان هذه النتيجة إلى: اللامركزية التي ترافق سير العمليات الإدارية لاى القيادات المدرسية، في إثراك الآخرين في التخطيط، والتي تغيب في التنفيذ. - حصلت الفقرة رقم (ه) والتي تنص على "الاعتماد على الأرقام والحقائق" على أدنى واقع جودة بمتوسط حسابي بلغ (Y.9v)، إضافة إلى تباين واضح في استجابات أفراد العينة حول

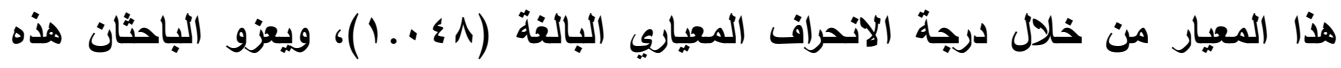
النتيجة إلى الآتي: نبذ العشوائية في اتخاذ بعض القرارات القيادية والإدارية نظرا لغياب أو تدني توافر الأرقام، أو قواعد البيانات التي في ضوئها تتخذ القرارات. سادساء معيار التقويم الإداري:

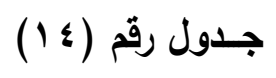

المتوسطات الحسابية والانحرافات المعيارية لتقديرات أفراد العينة لواقع اختيار قادة المدارس بالمرحلة الثانوية بمحافظة حفر الباطن في ضوء معايير السياق المؤسسي (التقويم الإداري)

\begin{tabular}{|c|c|c|c|c|c|}
\hline الالالة اللفية & الانحراف & المستوس & تبة & معيار التقويم الإداري & r \\
\hline عالية & .988 & 4.04 & 1 & تنوع الأهداف. القدرة على استخام أساليب تقويم متتوعة حسب & 1 \\
\hline عالية & 1.085 & 3.88 & 2 & $\begin{array}{r}\text { التخطيط لبحوث إجرائية بهذف تحسين العمليات } \\
\text { الإدارية. }\end{array}$ & 3 \\
\hline 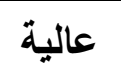 & 1.062 & 3.84 & 3 & تثخيص جوانب القوة لاى العاملين بغرض تنميتها. & 4 \\
\hline عالية & 1.202 & 3.75 & 4 & تثخيص جوانب الضعف لاى العاملين بغرض & 5 \\
\hline 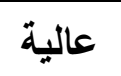 & 1.168 & 3.74 & 5 & تحديد الاحتياجات التريوية للعاملين بطرق علمية. & 2 \\
\hline 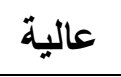 & 1.221 & 3.67 & 6 & توفير وسائل تقويم ذاتي للعاملين في المدرسة. & 6 \\
\hline 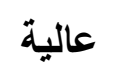 & 1.230 & 3.67 & 7 & تشجيع أسلوب تقويم الزملاء لبعضهم البعض. & 7 \\
\hline 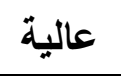 & 1.011 & 3.80 & & متوسط معيار التقويم الإداري ككل & \\
\hline
\end{tabular}


يتضح من الجدول رقم (ع 1) الآتي: إن واقع اختيار قادة المدارس بالمرحلة الثانوية بمحافظة حفر الباطن في ضوء معايير السياق المؤسسي (معيار التقويم الإداري) على واقع تطبيق

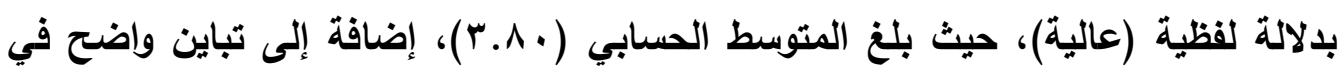
استجابات أفراد العينة حول هذا المعيار من خلال درجة الانحراف المعياري البالغة (1 (1 . ـ1)، ويعزو الباحثان هذه النتيجة إلى الآتي: ضرورة تطبيق وتفعيل مبادئ الجودة والاعتماد المدرسي في مدراس التعليم العام ومنها المدراس في المرحلة الثانوية. أما واقع اختيار قادة المدارس بالمرحلة الثانوية بمحافظة حفر الباطن في ضويء معايير السياق المؤسسي (معيار التقويم الإداري) على مستوى فقرات هذا المعيار فإنه يتضح من الجدول رقم (ع ال ) الآتي: - حصول الفقرة رقم (1) والتي تنص على أن "القدرة على استخدام أساليب تقويم متنوعة

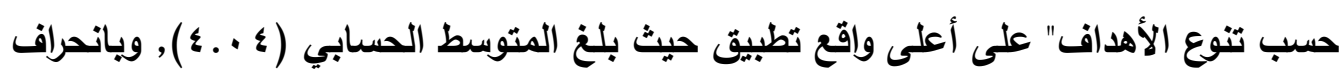

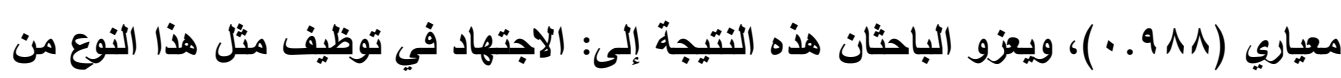
التقويم الإداري لتحقيق التميز القيادي. - حصلت الفقرة رقم (V) والتي تتص على "تثجيع أسلوب تقويم الزملاء لبعضهم البعض" على أدنى واقع جودة بمتوسط حسابي بلغ (V V.r)، إضافة إلى تباين واضح في استجابات

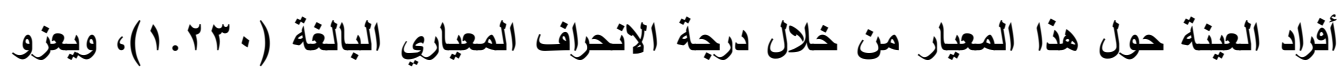
الباحثان هذه النتيجة إلى الآتي: ضرورة توظيف تقويم زملاء المهنة لبعض، وغياب التقويم الأاتي في المدارس الثانوية. الإجابة عن السؤال الثاني: هل توجد فروق ذات دلالة إحصائية في استجابات أفراد عينة الاراسة لواقع اختيار قادة

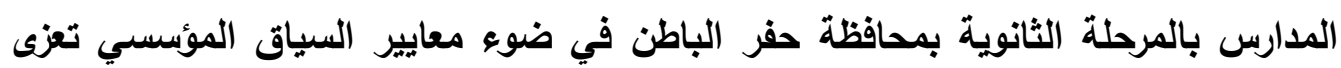
للمتغيرات (النوع الاجتماعي، المؤهل العلمي، المسمى الوظيفي، سنوات الخدمة)؟ 


\section{أولا بحسببمثفير النوعالاجتمامي:}

لفحص دلالات الفروق بين متوسطي استجابات أفراد العينة لواقع اختيار قادة المدارس بالمرحلة

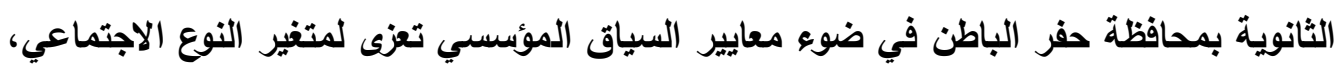

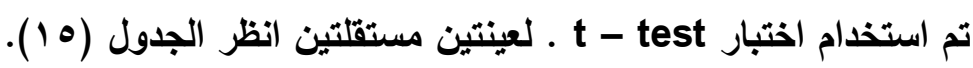

$$
\text { جدول (10) }
$$

نتائج فحص دلالة الفرق بين متوسطي تقديرات أفراد العينة لواقع اختيار قادة المدارس

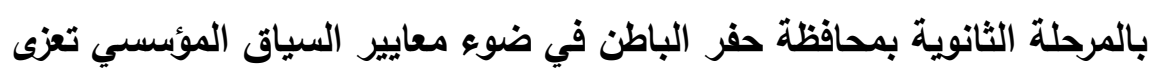
لمتغير النوع الاجتماعي

\begin{tabular}{|c|c|c|c|c|c|c|c|}
\hline الالالة & عالة & قالمسة & الانحراف & المتوبط & العدد & الاجتماعي النوع & المعايير \\
\hline \multirow{2}{*}{ غير } & \multirow{2}{*}{.771} & \multirow{2}{*}{-.291} & .877 & 3.61 & 27 & ذكور & \multirow{2}{*}{ الاستياغة الصيجية } \\
\hline & & & 1.160 & 3.68 & 157 & إناث & \\
\hline \multirow{2}{*}{ غير } & \multirow{2}{*}{.286} & \multirow{2}{*}{-1.070} & .843 & 3.62 & 27 & ذكور & \multirow{2}{*}{ التحليل البيئي } \\
\hline & & & 1.055 & 3.84 & 157 & إناث & \\
\hline \multirow{2}{*}{ غير } & \multirow{2}{*}{.727} & \multirow{2}{*}{-.350} & .728 & 3.97 & 27 & ذكور & \multirow{2}{*}{ الصفات المهنية } \\
\hline & & & .952 & 4.04 & 157 & إناث & \\
\hline \multirow{2}{*}{ غير } & \multirow{2}{*}{.799} & \multirow{2}{*}{.255} & .780 & 4.18 & 27 & ذكور & \multirow{2}{*}{ العلاقات الإنسانية } \\
\hline & & & .956 & 4.13 & 157 & إناث & \\
\hline \multirow{2}{*}{ غير } & \multirow{2}{*}{.668} & \multirow{2}{*}{-.429} & .773 & 4.02 & 27 & ذكور & \multirow{2}{*}{ الاتصال } \\
\hline & & & .970 & 4.10 & 157 & إناث & \\
\hline \multirow{2}{*}{ غير } & \multirow{2}{*}{.242} & \multirow{2}{*}{-1.175} & .809 & 3.59 & 27 & ذكور & \multirow{2}{*}{ التقويم الإداري } \\
\hline & & & 1.039 & 3.83 & 157 & إناث & \\
\hline \multirow{2}{*}{ غير } & \multirow{2}{*}{.566} & \multirow{2}{*}{-.576} & .724 & 3.83 & 27 & ذكور & \multirow{2}{*}{ معايير السياق } \\
\hline & & & .925 & 3.94 & 157 & إناث & \\
\hline
\end{tabular}


يتضح من الجدول (0 1 ) بأنه:

لا توجد فروق ذات دلالة إحصائية عند مستوى دلالة ( ه .,. ) بين متوسطي

استجابات أفراد العينة لواقع اختيار قادة المدارس بالمرحلة الثانوية بمحافظة حفر الباطن في دله

ضوء معايير السياق المؤسسي تعزى لمتفير النوع الاجتماعي ويعزو الباحثان ذلك إلى أن المعلمين والمعلمات يعيثون في البيئة التعليمية، ولهم نفس الثقافة التنظيمية، ويعيشون في

نفس المناخ التنظيمي.

ثانيا بحسب متغير المؤهل العلمي:

لفحص دلالات الفروق بين متوسطي استجابات أفراد العينة لواقع اختيار قادة المدارس بالمرحلة الثانوية بمحافظة حفر الباطن في ضوء معايير السياق المؤسسي تعزى لمتغير المؤهل العلمي، تم استخدام اختبار test - te ـ لعينتين مستقلتين انظر الجدول (7 إئ ).

$$
\text { جدول (17) }
$$

نتائج فحص دلالة الفرق بين متوسطي تقديرات أفراد العينة لواقع اختيار قادة المدارس بالمرحلة الثانوية بمحافظة حفر الباطن في ضوء معايير السياق المؤسسي تعزى لمتغير

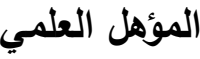

\begin{tabular}{|c|c|c|c|c|c|c|c|}
\hline اللفظية اللالة & عالة & قالمحسوبية & الانحراف & المتوبط الحسابي & العدد & المؤهل & المعايير \\
\hline \multirow[b]{2}{*}{ دالة } & \multirow[b]{2}{*}{.002} & \multirow[b]{2}{*}{3.359} & 1.146 & 3.72 & 168 & بكالوريوس & \multirow{2}{*}{ الاستراتيجة } \\
\hline & & & .612 & 3.12 & 16 & أعلى من & \\
\hline \multirow[b]{2}{*}{ غير دالة } & \multirow[b]{2}{*}{.594} & \multirow[b]{2}{*}{.534} & 1.040 & 3.82 & 168 & بكالوريوس & \multirow[b]{2}{*}{ التئيل } \\
\hline & & & .909 & 3.68 & 16 & أعلى من & \\
\hline
\end{tabular}




\begin{tabular}{|c|c|c|c|c|c|c|c|}
\hline اللالالة & دالة & قالمحسويية & الانحراف & المتوبط الحسابي & العدد & المؤهل & المعايير \\
\hline \multirow[b]{2}{*}{ غير دالة } & \multirow[b]{2}{*}{.763} & \multirow[b]{2}{*}{.303} & .930 & 4.04 & 168 & بكالوريوس & \multirow[b]{2}{*}{ الصفات المهنية } \\
\hline & & & .844 & 3.96 & 16 & أعلى من & \\
\hline \multirow[b]{2}{*}{ غير دالة } & \multirow[b]{2}{*}{.259} & \multirow[b]{2}{*}{1.132} & .926 & 4.16 & 168 & بكالوريوس & \multirow{2}{*}{ الإنساتاتة } \\
\hline & & & .969 & 3.89 & 16 & أعلى من & \\
\hline \multirow[b]{2}{*}{ غير دالة } & \multirow[b]{2}{*}{.441} & \multirow[b]{2}{*}{.772} & .952 & 4.11 & 168 & بكالوريوس & \multirow[b]{2}{*}{ الاتصال القيادي } \\
\hline & & & .837 & 3.92 & 16 & أعلى من & \\
\hline \multirow[b]{2}{*}{ غير دالة } & \multirow[b]{2}{*}{.262} & \multirow[b]{2}{*}{1.125} & 1.018 & 3.82 & 168 & بكالوريوس & \multirow{2}{*}{ الإداري } \\
\hline & & & .918 & 3.53 & 16 & أعلى من & \\
\hline \multirow[b]{2}{*}{ غير دالة } & \multirow[b]{2}{*}{.265} & \multirow[b]{2}{*}{1.118} & .910 & 3.95 & 168 & بكالوريوس & \multirow{2}{*}{ المعائير } \\
\hline & & & .732 & 3.68 & 16 & أعلى من & \\
\hline
\end{tabular}

يتضح من الجدول (7 1 ) بأنه: لا توجد فروق ذات دلالة إحصائية عند مستوى دلالة ( ه.,. ) ) بين متوسطي استجابات أفراد العينة لواقع اختيار قادة المدارس بالمرحلة الثانوية بمحافظة حفر الباطن في ضوء معايير السياق المؤسسي، باستثناء معيار الصياغة الاستراتيجية، تعزى لمتغير المؤهل العلمي ويعزو الباحثان ذلك إلى الفكر القيادي الذي تتمتع به القيادات المدرسية لممارستهم القيادية، والذي ينصهر فيه الجميع دون تمييز في الارجة المؤهل العلمي. 


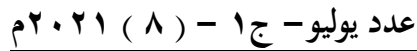

تصور مقترح لتطوير

توجد فروق ذات دلالة إحصائية عند مستوى دلالة ( ه.,. ) بين متوسطي

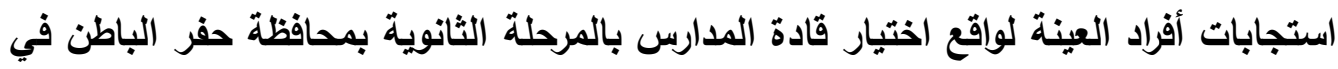
ضوء معايير السياق المؤسسي (معيار الصياغة الاستراتيجية)، تعزى لمتفير المؤهل العلمي،

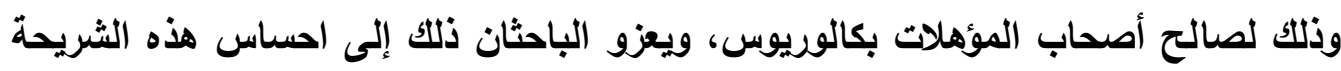
في هذا المعيار أنهم امتلكوا الخبرة والمعرفة العلمية الكافية في الصياغة الاستراتيجية

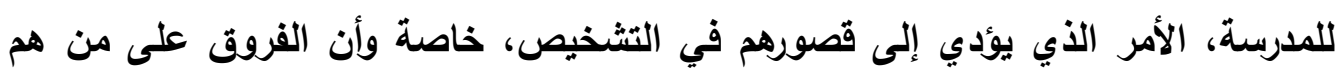
أعلى منهم في الرتبة العلمية.

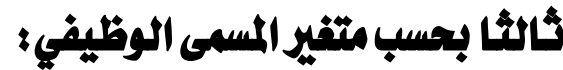

لفحص دلالات الفروق بين متوسطي استجابات أفراد العينة لواقع اختيار قادة الدارس

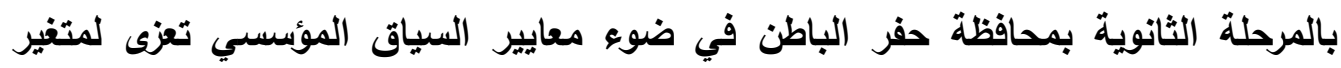

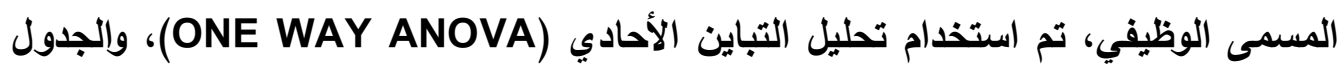

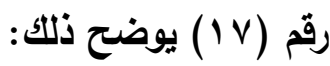




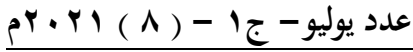

تصور مقترح لنطوير ...

جدول (IV) Vتائج فحص دلالة الفرق بين متوسطي تقديرات أفراد العينة لواقع اختيار قادة المدارس بالمرحلة الثانوية بمحافظة حفر الباطن في ضوء معايير السياق المؤسسي تعزى لمتغير المسمى الوظيفي

\begin{tabular}{|c|c|c|c|c|c|c|c|}
\hline اللفظية & مستوى الالاية & $\begin{array}{c}\text { F } \\
\text { قيمة }\end{array}$ & متوسط المريعات & الحرية & المربعات & \multicolumn{2}{|c|}{ المعايير } \\
\hline \multirow{3}{*}{ غير } & \multirow{3}{*}{.086} & 2.48 & 3.073 & 2 & 6.146 & بين المجموعات & \multirow{3}{*}{ الاستراتيجية } \\
\hline & & 3 & 1.238 & 181 & 224.014 & داخل المجموعات & \\
\hline & & & & 183 & 230.160 & التباين الكلي & \\
\hline \multirow{3}{*}{ 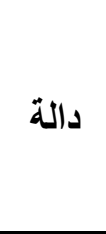 } & \multirow{3}{*}{.019} & 4.04 & 4.136 & 2 & 8.271 & بين المجموعات & \multirow{3}{*}{ التحليل } \\
\hline & & 5 & 1.022 & 181 & 185.041 & داخل المجموعات & \\
\hline & & & & 183 & 193.312 & التباين الكلي & \\
\hline \multirow{3}{*}{ دالة } & \multirow{3}{*}{.051} & 3.02 & 2.514 & 2 & 5.028 & بين المجموعات & \multirow{3}{*}{ الصفات } \\
\hline & & 7 & .830 & 181 & 150.305 & داخل المجموعات & \\
\hline & & & & 183 & 155.333 & التباين الكلي & \\
\hline \multirow{3}{*}{ دالة } & \multirow{3}{*}{.004} & 5.77 & 4.750 & 2 & 9.500 & بين المجموعات & \multirow{3}{*}{ الإنسانية } \\
\hline & & 1 & .823 & 181 & 148.974 & داخل المجموعات & \\
\hline & & & & 183 & 158.474 & التباين الكلي & \\
\hline \multirow{3}{*}{ غير } & \multirow{3}{*}{.055} & 2.95 & 2.569 & 2 & 5.138 & بين المجموعات & \multirow{3}{*}{ الاتصال } \\
\hline & & 5 & .869 & 181 & 157.352 & داخل المجموعات & \\
\hline & & & & 183 & 162.490 & التباين الكلي & \\
\hline \multirow{3}{*}{ دالة } & \multirow{3}{*}{.048} & 3.08 & 3.084 & 2 & 6.168 & بين المجموعات & \multirow{3}{*}{ الإلتقاري } \\
\hline & & 9 & .998 & 181 & 180.701 & داخل المجموعات & \\
\hline & & & & 183 & 186.870 & التباين الكلي & \\
\hline \multirow{3}{*}{ دالة } & \multirow{3}{*}{.022} & \multirow{3}{*}{3.909} & 3.048 & 2 & 6.097 & بين المجموعات & \multirow{3}{*}{ 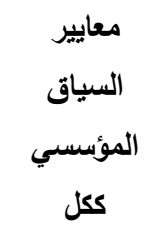 } \\
\hline & & & .780 & 181 & 141.171 & داخل المجموعات & \\
\hline & & & & 183 & 147.268 & التباين الكلي & \\
\hline
\end{tabular}


يتبين من الجدول (IV) الآتي: لا توجد فروق ذات دلالة إحصائية عند مستوى دلالة ( ه.., . ) بين متوسطي استجابات أفراد العينة لواقع اختيار قادة المدارس بالمرحلة الثانوية بمحافظة حفر الباطن في دله

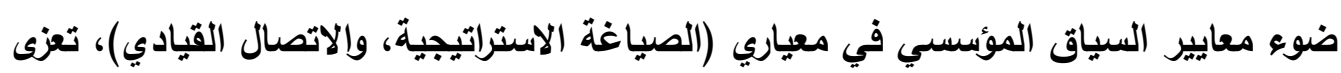

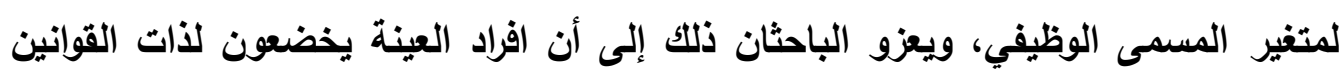
والتشريعات والأنظمة، حيث تثرف عليهم قيادة عليا واحدة ممثلة بوزارة التعليم، وإدارة التعليم في المحافظة. توجد فروق ذات دلالة إحصائية عند مستوى دلالة ( ه., . ) بين متوسطي استجابات أفراد العينة لواقع اختيار قادة المدارس بالمرحلة الثانوية بمحافظة حفر الباطن في دلائه ضوء معايير السياق المؤسسي (التحليل البيئي، الصفات المهنية، العلاقات الإنسانية، التقويم الإداري)، إضافة إلى معايير السياق المؤسسي ككل، تعزى لمتغير المسمى الوظيفي. ولمعرفة من تؤول إليه الفروق في واقع اختيار قادة المدارس بالمرحلة الثانوية بمحافظة حفر الإني الباطن في ضوء معايير السياق المؤسسي (التحليل البيئي، الصفات المهنية، العلاقات

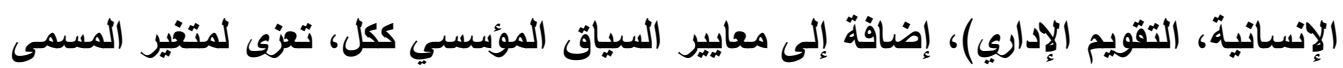

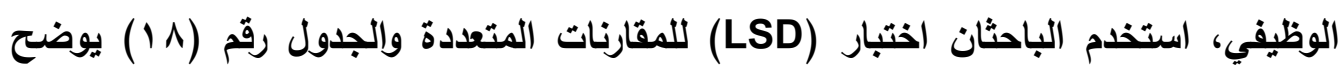
ذزلك: 


$$
\text { جدول رقم (1) }
$$

نتائج اختبار (LSD) للمقارنات المتعددة بين متوسطات استجابات أفراد العينة لواقع اختيار قادة المدارس بالمرحلة الثانوية بمحافظة حفر الباطن في ضوء معايير السياق المؤسسي المئي

\begin{tabular}{|c|c|c|c|c|}
\hline \multicolumn{5}{|c|}{ تعزى لمتغير المسمى الوظيفي } \\
\hline \multicolumn{5}{|c|}{ LSD } \\
\hline الالالة & الاختلاف في & (J)(المسمى الوظيفي & (الوظلافيفى & لمحاور والمجالات \\
\hline .323 & .263 & وكيل/ة & \multirow{2}{*}{ 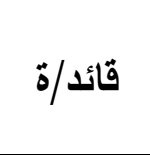 } & \multirow{2}{*}{ التحليل البيئي } \\
\hline .005 & $.480 *$ & معلم/2 & & \\
\hline .102 & .394 & وكيل/ة & \multirow{2}{*}{ 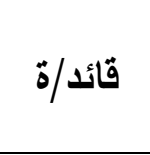 } & \multirow{2}{*}{ الصفات المهنية } \\
\hline .019 & $.362 *$ & معم//ة & & \\
\hline .170 & .329 & وكيد/ة & \multirow{2}{*}{ ق ق قائد/ة } & \multirow{2}{*}{ الالإنسانية } \\
\hline .001 & $.517 *$ & معلم/ة & & \\
\hline .055 & .511 & وكيد/ة & \multirow{2}{*}{ ق قائد/ة } & \multirow{2}{*}{ التقويم الإداري } \\
\hline .026 & $.376 *$ & معلم//ة & & \\
\hline .238 & .275 & وكيل/ة & \multirow{2}{*}{ ق قائد/ة } & \multirow{2}{*}{ معايير السياق } \\
\hline .006 & $.414^{*}$ & معلم//ة & & \\
\hline
\end{tabular}

يتبين من الجدول (1 إ) الآتي:

توجد فروق ذات دلالة إحصائية عند مستوى دلالة ( ه., . ) بين متوسطي استجابات

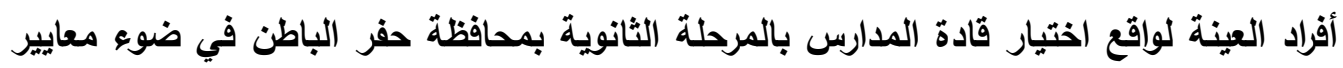
السياق المؤسسي (التحليل البيئي، الصفات المهنية، العلاقات الإنسانية، التقويم الإداري)، إضافة العافية

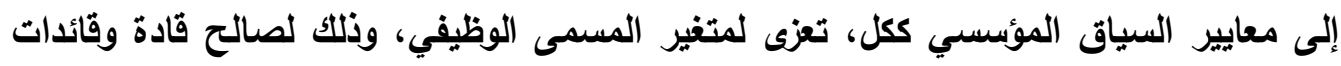

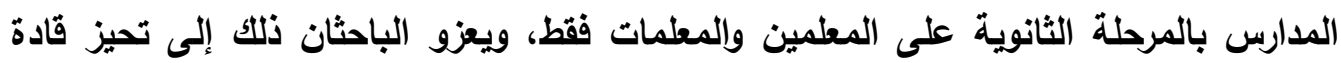


وقائدات المدارس في استجاباتهم على استجابات المعلمين والمعلمات، ما يعني أن تثخيص

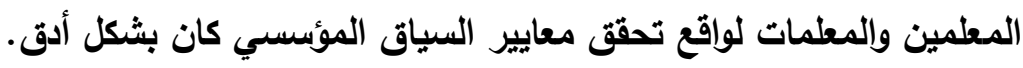

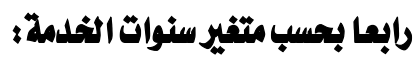

لفحص دلالات الفروق بين متوسطي استجابات أفراد العينة لواقع اختيار قادة المدارس بالمرحلة الثانوية بمحافظة حفر الباطن في ضوء معايير السياق المؤسسي تعزى لمتغير سنوات الخدمة،

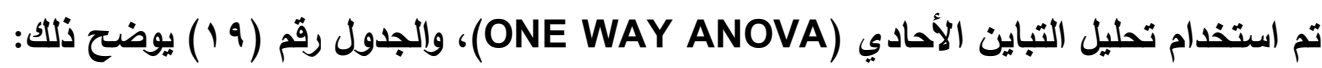

$$
\text { جدول (19) }
$$

نتائج فحص دلالة الفرق بين متوسطي تقديرات أفراد العينة لواقع اختيار قادة المدارس بالمرحلة

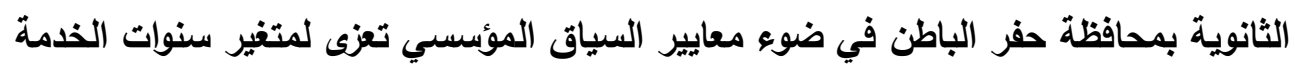

\begin{tabular}{|c|c|c|c|c|c|c|c|}
\hline اللفظية & مستو & $\begin{array}{c}\text { F } \\
\text { قيمة }\end{array}$ & متوبط المربعات & الحرية & المربعات & \multicolumn{2}{|c|}{ المعاييز } \\
\hline \multirow{3}{*}{ غير } & \multirow{3}{*}{.636} & \multirow{3}{*}{.569} & .720 & 3 & 2.161 & بين المجموعات & \multirow{3}{*}{ الاستراتيجية } \\
\hline & & & 1.267 & 180 & 228.000 & داخل المجموعات & \\
\hline & & & & 183 & 230.160 & التباين الكلي & \\
\hline \multirow{3}{*}{ غيلة } & \multirow{3}{*}{.476} & \multirow{3}{*}{.836} & .886 & 3 & 2.657 & بين المجموعات & \multirow{3}{*}{ التيئي } \\
\hline & & & 1.059 & 180 & 190.655 & داخل المجموعات & \\
\hline & & & & 183 & 193.312 & التباين الكلي & \\
\hline \multirow{3}{*}{ غير } & \multirow{3}{*}{.056} & \multirow{3}{*}{2.589} & 2.141 & 3 & 6.424 & بين المجموعات & \multirow{3}{*}{ الصفات } \\
\hline & & & .827 & 180 & 148.908 & داخل المجموعات & \\
\hline & & & & 183 & 155.333 & التباين الكلي & \\
\hline \multirow{3}{*}{ غير } & \multirow{3}{*}{.118} & \multirow{3}{*}{1.981} & 1.688 & 3 & 5.065 & بين المجموعات & \multirow{3}{*}{ العلاقات } \\
\hline & & & .852 & 180 & 153.409 & داخل المجموعات & \\
\hline & & & & 183 & 158.474 & التباين الكلي & \\
\hline \multirow{2}{*}{ غير } & \multirow[t]{2}{*}{.543} & \multirow[t]{2}{*}{.717} & .640 & 3 & 1.919 & بين المجموعات & \multirow{2}{*}{ الاتصال } \\
\hline & & & .892 & 180 & 160.571 & داخل المجموعات & \\
\hline
\end{tabular}




\begin{tabular}{|c|c|c|c|c|c|c|c|}
\hline & & & & 183 & 162.490 & التباين الكلي & \\
\hline \multirow{3}{*}{ غير } & \multirow{3}{*}{.055} & \multirow{3}{*}{2.582} & 2.570 & 3 & 7.709 & بين المجموعات & \multirow{3}{*}{ الإداري } \\
\hline & & & .995 & 180 & 179.160 & داخل المجموعات & \\
\hline & & & & 183 & 186.870 & التباين الكلي & \\
\hline \multirow{3}{*}{ غير } & \multirow{3}{*}{.203} & \multirow{3}{*}{1.550} & 1.236 & 3 & 3.709 & بين المجموعات & \multirow{3}{*}{ الموئير } \\
\hline & & & .798 & 180 & 143.559 & داخل المجموعات & \\
\hline & & & & 183 & 147.268 & التباين الكلي & \\
\hline
\end{tabular}

يتبين من الجدول (9 1 ) الآتي:

لا توجد فروق ذات دلالة إحصائية عند مستوى دلالة ( ه.,. ) بين متوسطي استجابات أفراد العينة لواقع اختيار قادة المدارس بالمرحلة الثانوية بمحافظة حفر الباطن في ضوء معايير السياق المؤسسي، تعزى لمتغير سنوات الخدمة، ويعزو الباحثان ذلك إلى وحدة القوانين والتثريعات والنظم التي تلتزم بها القيادات المدرسية، إضافة إلى تثابه الأعمال الروتينية التي يقومون بها. لإجابة عن السؤال الثالث: ما التصور المقترح لتطوير اختيار قادة المدارس بالمرحلة الثانوية بمحافظة حفر الباطن في ضوء معاييز السياق المؤسسي؟

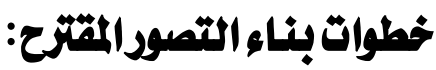
تم بناء التصور المقترح وفق مجموعة من الخطوات بدأت بتحديد المبررات، والمنطلقات، والأهداف،

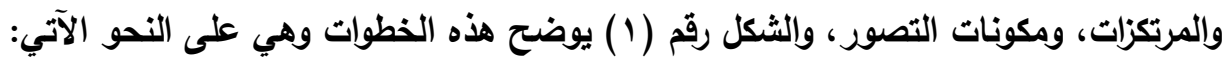
1- ا مبررات التصور. r - r المنطلقات الفكرية للتصور. r- r أهداف التصور. ع - مرتكزات التصور . - م

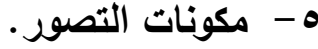




\section{الثتصور المكتر ح}

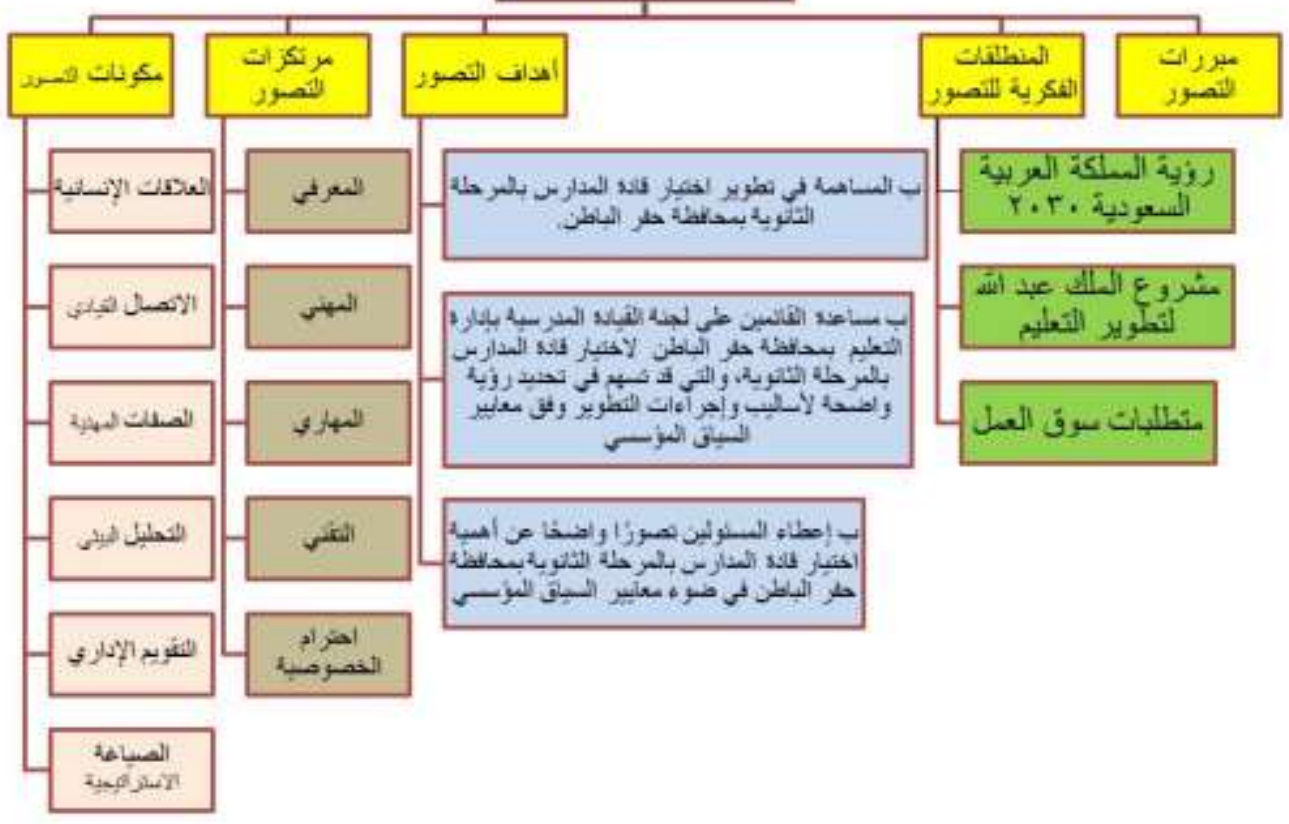

شكل (1)

شكل التصور المقترح

المصدر: من إعداد الباحثان

بررات التصورالثقتزح: بمان

بما أن معايير السياق المؤسسي: أحد الاتجاهات المعاصر في التطوير والتحسين، ويما أن درجة الأهمية درجة أهمية اختيار قادة المدارس بالمرحلة الثانوية بمحافظة حفر الباطن في ضوء معايير السياق المؤسسي كانت عالية وعالية جدا، انبثقت أهمية بناء التصور المقترح لتطوير اختيار قادة المدارس بالمرحلة الثانوية بمحافظة حفر الباطن.

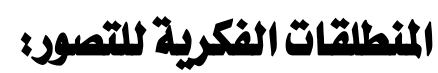
ا. روئة المملكة العربية السعودية •r.r، التي من أهدافها في المجال التعليمي الارتقاء بجودة التعليم، وريط التعليم بسوق العمل. 
r. مشروع خادم الحرمين الشريفين الملك عبد الله بن عبد العزيز - رحمه الله - لتطوير

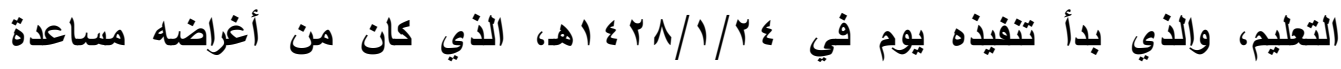
المؤسسات التريوية على استيعاب الظروف المتغيرة والتعامل معها، والتمتع بمنظومة من القيم والتوجيهات المهنية. ويعدُّ مشروع الملك عبدالله بن عبدالعزيز لتطوير التعليم العام "تظوير" مبادرة وطنية تهذف إلى تحقق روئة القيادة في تطوير التعليم العام في المملكة

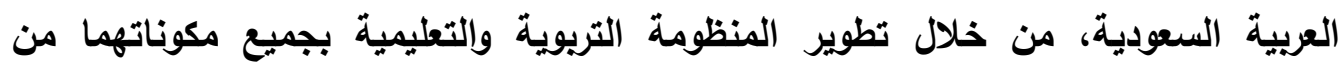

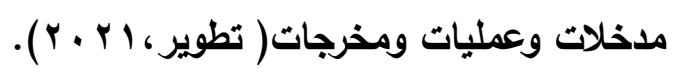

كما يعد مشروع الملك عبدالله بن عبد العزيز أضخم مشروع يشهده تطوير التعليم في المملكة العربية السعودية، والذي يمثل إرادة القيادة، والرغبة المهنية لخطط تطوير التعليم العام، حيث يهاف "تظوير" إلى الإسهام الفعال في الرفع من قدرة المملكة التنافسية، ويناء

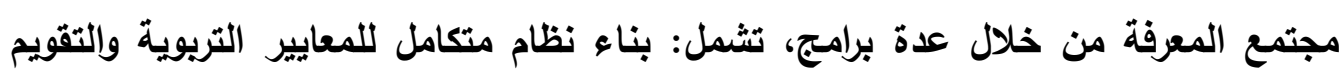

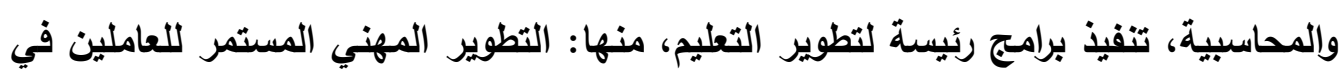
التعليم جميعهم، تطوير المناهج ومواد التعلم، وتحسين البيئة المدرسية وتوظيف تقنية المعلومات لتعزيز وتحسين التعليم و التعلم ، والأنشطة غير الصفية والخدمات الطلابية. كما وندين

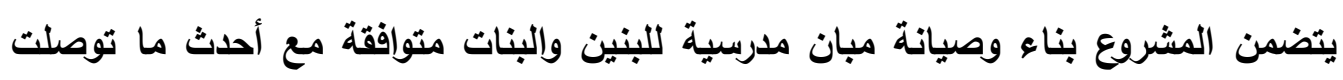

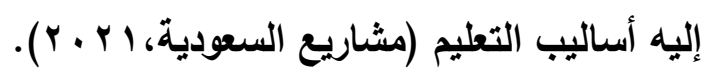

r. متطلبات سوق العمل: حيث يواجه الخريجين تحدي سوق العمل، و الالتحاق بمؤسسات بالتعليم العالي والمهني؛ ليصبحوا مواطنين قادرين على تلبية متطلبات سوق التول

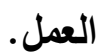

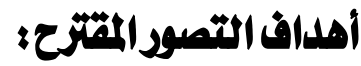

- - - مساهمة في تطوير اختيار قادة المدارس بالمرحلة الثانوية بمحافظة حفر الباطن.

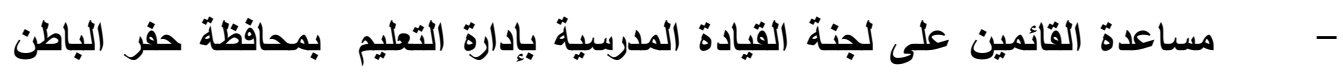
لاختيار قادة المدارس بالمرحلة الثانوية، والتي قد تسهم في تحديد روئة واضحة لأساليب وإجراءات التطوير وفق معايير السياق المؤسسي. لادهي. 
إعطاء المسئولين تصورًا واضحًا عن أهمية اختيار قادة المدارس بالمرحلة الثانوية

بمحافظة حفر الباطن في ضوء معايير السياق المؤسسي.

\section{مرهزات التصور:}

يستند التصور إلى المرتكزات الآتية:

1-المرتكز المعرفي: بحيث يتضمن معايير الاختيار وفق مبادئ والاتجاهات الحديثة في الإدارة والقيادة وما يستجد فيهما. 2-المرتكز المهني: والذي يرتبط بمهنة القيادة المدرسية، والمهارات العلمية وأخلاقياتها

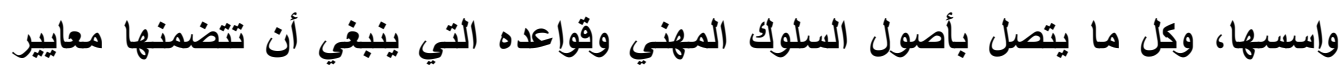
الاختيار. 3-المرتكز المهاري: ويتضمن مدى توافر المهارات والقدرات التي تعمل على تحسين ممارسة المسؤوليات والمهام الوظيفية للقيادات المدرسية على تثخيص المواقف القيادية المئية المختلفة، والتوصل لحلها.

4-المرتكز التقتي: ويتمثل في الاستفادة من التقدم التقني في توظيف المستحدثات التقتية

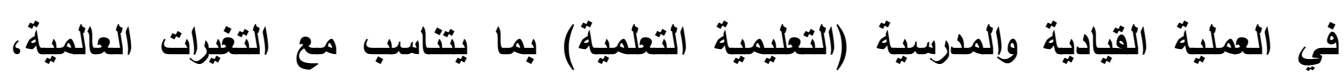
واتجاهات الفكر القيادي في القرن الحادي والعشرين.. 5-احترام الخصوصية: يركز التصور على احترام خصوصية المعلمين والمعلمات والإداريين والإداريات، ولا سيما في وجود بيئة مفتوحة داعمة للتقنية، وتستخدم أجهزة الاستشعار

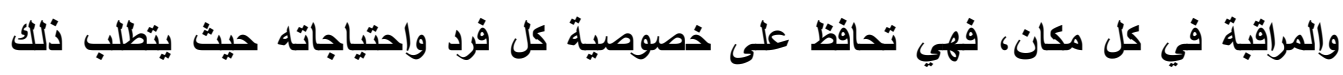
الأمانة والرقابة الشديدة على الأنظمة التقتية.

\section{مكوخات التصورالمثمزح?}

يتكون التصور المقترح من ستة معايير رئيسة وهي بحسب درجة أهميتها (العلاقات

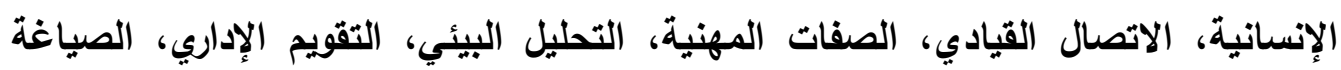

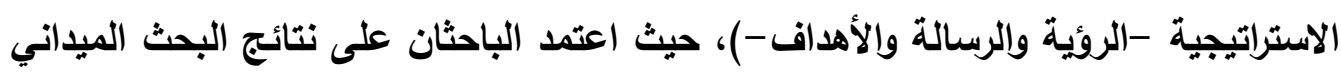
أساسًا لبناء التصور المقترح، حسب المعايير الفرعية التي تتضمن (بـ ؛ معيار فرعي. 
1 - المحافظة على سرية بيانات العاملين. - احترام خصوصية الآخرين. - استخدام كلمات إيجابية في التعامل مع الآخرين

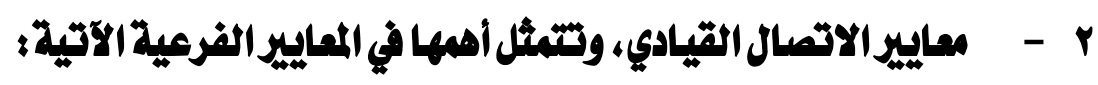
- عقد لقاءات دورية مع المعنيين (معلمين، مجلس آباء، مجلس أمهات).

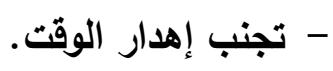
- تجنب الكلام بغياب الشخص المعني.

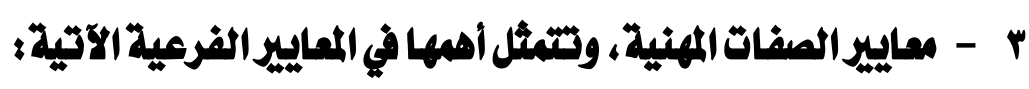
- الالتزام بحدود المسؤولية القيادية.

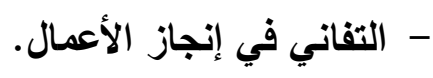
- معالجة المشاكل المدرسية.

ع - معاير التحليل البيئي، وتمثل أهمها في المعايير الثرمية الآتية: - توظيف تقنيات التعليم الحديثة في العملية التعليمية. - تدريب المعلمين بغرض تحسين نوعية التعليم. - رصد التغيرات المتسارعة في بيئة التعليم.

0 - معايير التقويم الإداري، وتشمثل أهمها في المعايريز الثرعية الآتية: - القدرة على استخدام أساليب تقويم متنوعة حسب تنوع الأهداف. - التخطيط لبحوث إجرائية بهدف تحسين العمليات الإدارية. - تشخيص جوانب القوة لاى العاملين بغرض تنميتها.

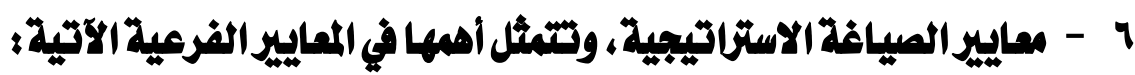
- وضع روية واضحة تعبر عما تطمح إليه المدرسة. - مراجعة رسالة المدرسة بشكل دوري بما يتناسب مع التوجهات العامة للمملكة العربية السعودية. - تحديد الأهداف الاستراتيجية لمجالات التطوير المستقبلية للمدرسة. 


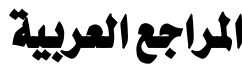

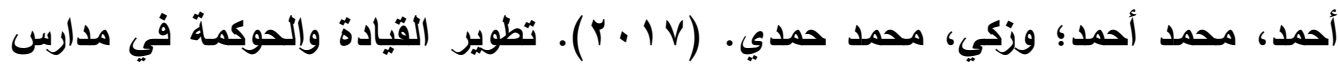
التعليم العام في ضوء المعايير القومية للتقويم والاعتماد دراسة حالة محافظة المنيا، المجلة

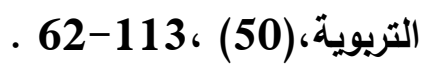

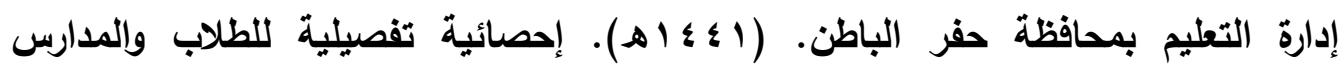
والمعلمين للعام الدراسي ·ـ؛ ا-1441 لإدارة التعليم بمحافظة حفر الباطن، التخطيط والتطوير بإدارة التعليم بمحافظة حفر الباطن.

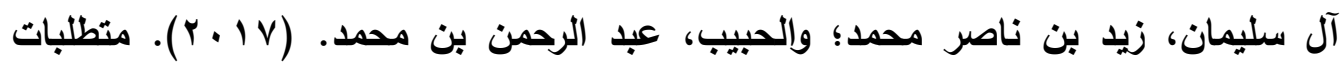
تطوير أداء القيادات المدرسية في ضوء معايير جودة القيادة المدرسية لهيئة تقويم التعليم بالمملكة العربية السعودية، مجلة كلية التربية الأساسية للعلوم التريوية والإنسانية بجامعة فئية

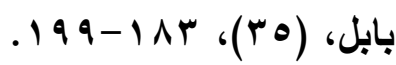

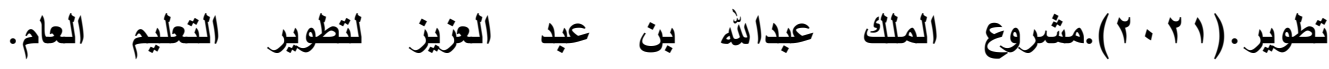
.http://www.tatweer.demo4dev.com/ar/3402 حسن، نوف نثمي. (Y. V. V). تطوير معايير اختيار مديرات مدارس المرحلة الثانوية بوزارة

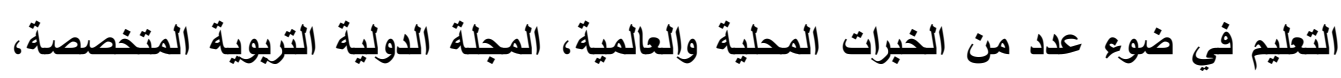
$.9 \vee-\Lambda \cdot ،(\xi) 4$

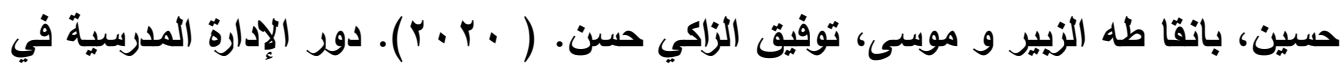
تحقيق الأهداف التريوية والتعليمية من وجهة نظر المشرفين التريويين بمرحلة التعليم

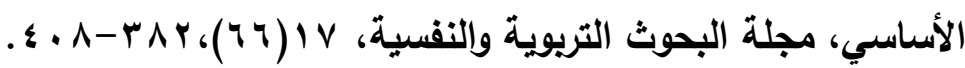
الحية، وليد نمر. (10 ب (10). درجة ممارسة مديري الدارس الثانوية للإدارة الاستراتيجية وعلاقتها بتحقيق التميز الإداري، [رسالة ماجستير غير منشورة]، الجامعة الإسلامية بغزة، فلنطين. الارعان، وليد زامل. (9 ( ب ). مستوى رضا وكلاء مدارس التطليم العام بمدينة تبوك عن

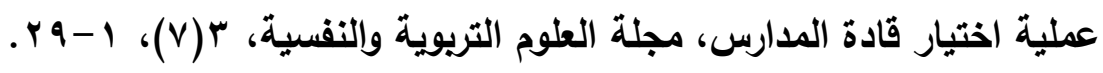




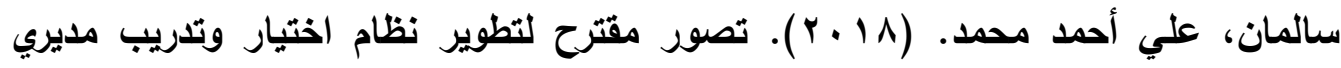
المدارس الابتدائية في المملكة العربية السعودية في ضوء خبرات بعض الدول، مجله مجلة كلية

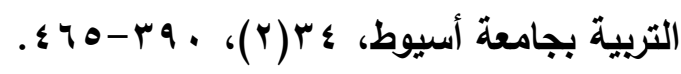

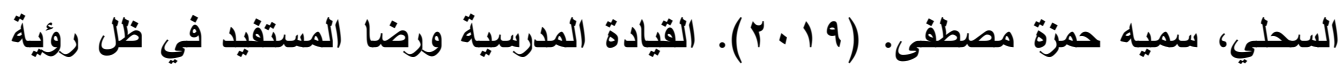

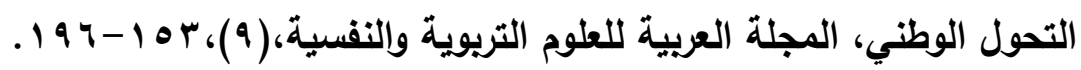

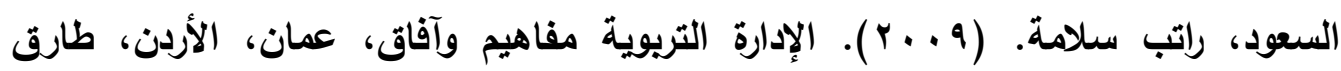
لإمات المكتبية. الثايع، علي بن صالح. (1 (1 ب). معايير اختيار القيادات المدرسية من منظور التربية الإسلامية ومدى توافرها في مديري المدارس الثانوية بمنطقة القصيم، مجلة جامعة خالد

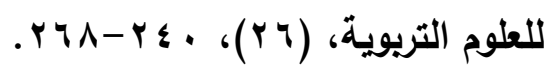

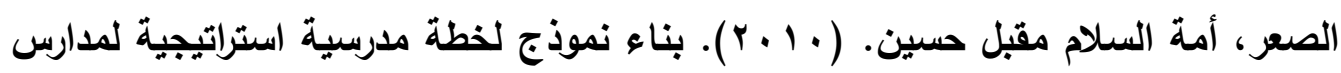
التعليم العام في الجمهورية اليمنية، [رسالة ماجستير غير منشورة]، جامعة صنعاء، اليمن.

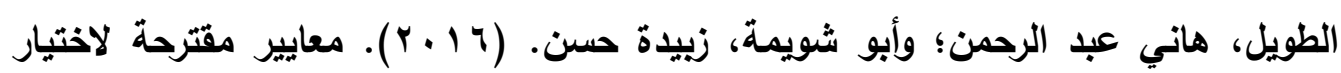

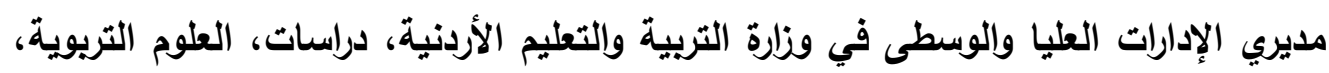
.929-947،43(2) عبودي، زيد عبودي. (· ( • ( ). دور القيادة التريوية في اتخاذ القرارات الإدارية. عمان: دار الشروق.

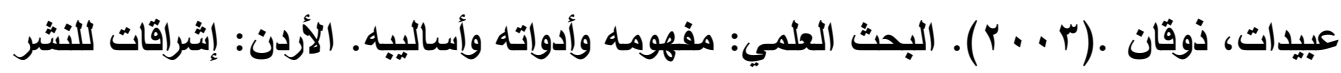
والتوزيع. العساف، صالح بن محمد. (r ا ـ ץ). المدخل إلى البحث في العلوم السلوكية. طץ ـ الرياض: دار الزهراء للنشر والتوزيع.

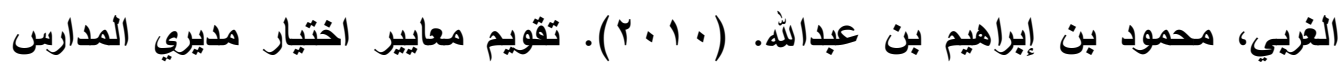
الثانوية بالمملكة العربية السعودية، [رسالة ماجستير غير منشورة]، جامعة صنعاء، اليمن. 


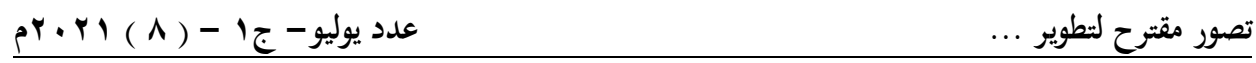

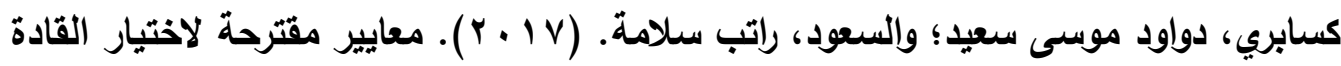
التريويين في المدارس الخاصة في فلسطين في ضوء الواقع وأبعاد الجودة الثخصية، دراسات

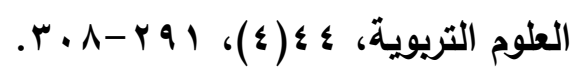

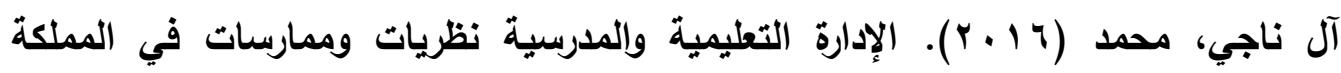
العربية السعودية. طV. الرياض: مطابع الحميضي.

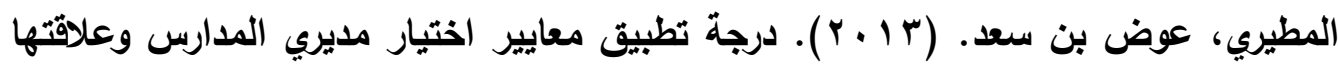
بفاعلية أدائهم لمهامهم الفنية من وجهة نظر المشرفين التربويين بمنطقة المدينة المنورة، [رسالة ماجستير غير منشورة]، جامعة مؤتة، الأردن. النصير، يوسف محمد؛ والقيسي، حسين عبد النبي؛ والرواشدة، ناجي محمد عواد. (7 1 ץ). درجة تطبيق معايير الجودة (السياق المؤسسي) في مؤسسات التعليم العالي الأردنية

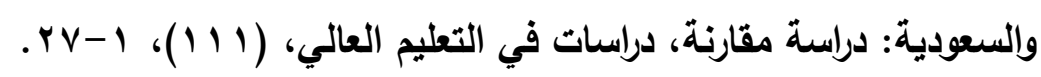

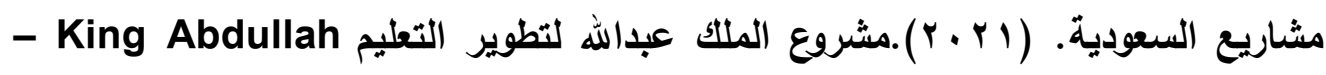
. https://2u.pw/BdEfj.Project for General Education Development

$$
\text { وأضف|صحت معلومة }
$$

Berwari, N. \& Bashiwa, H. (2011). Quality Management Introduction to excellence: concepts, foundations and applications. Amman: Dar Al- Waraq for publishing and distribution. Frank S. Del Favero-(2019). Rowman \& Littlefield Publishing Group> 
